Bruno Škreblin

\title{
ULOGA OBITELJSKIH VEZA U FORMIRANJU GRADSKE ELITE ZAGREBAČKOG GRADECA*
}

Bruno Škreblin

Hrvatski institut za povijest

Zagreb

\author{
UDK 929.52(497.5Zagreb)"13/15" \\ 316.344.42(497.5Zagreb)"13/15" \\ Izvorni znanstveni rad \\ Primljeno: 15.6.2016. \\ Prihvaćeno: 16.11.2016. \\ DOI: http://doi.org/10.21857/yk3jwhkwo9
}

\begin{abstract}
$U$ radu se analizira uloga obiteljskih veza u formiranju gradske elite na zagrebačkom Gradecu u vremenu od sredine 14. do početka 16. stoljeća. Na temelju izvornih podataka prvo se utvrđuju vršitelji funkcija, najviše gradski suci o kojima je sačuvano više podataka, a potom se identificiraju njihovi nasljednici ili članovi istih obitelji. Drugi dio donosi osvrt na neke značajke srednjovjekovnih gradskih obitelji, a u prilogu se nalaze tabele i genealoški prikazi najznačajnijih gradskih obitelji.

Ključne riječi: Zagrebački Gradec, gradska elita, povijest obitelji, srednji vijek, društvena povijest
\end{abstract}

\section{Uvod i historiografija}

O povezanosti obiteljskih i rodbinskih veza te formiranju društvenih i političkih elita u historiografiji je dosad mnogo raspravljano. Općenito gledajući, moglo bi se reći da su obiteljske i rodbinske veze još odavno privukle pažnju starijih povjesničara koji su tradicionalnim pristupom pisali o najznačajnijim obiteljima - onim kraljevskim ili moćnih plemića, da bi se potom fokus proširio i na ostale utjecajne obitelji, u prvom redu u najznačajnijim urbanim sredinama srednjovjekovne Europe. ${ }^{1}$

Ovaj je rad sufinancirala Hrvatska zaklada za znanost projektom Gradovi hrvatskog srednjovjekovlja: Urbane elite i urbani prostor (HRZZ-IP-09-2014-7235).

1 U domaćoj historiografiji početak istraživanja plemićkih obitelji datira još od druge polovine 19. st., usporedno s prikupljanjem i objavljivanjem arhivske građe o pojedinim plemićkim rodovima. Jedan od značajnih povjesničara u domaćoj historiografiji bio je Vjekoslav Klaić koji je objavljivao studije i monografije o pojedinim plemićkim obiteljima (Bribirski knezovi: Od plemena Śubić do 1347., Zagreb 1897.; Krčki knezovi Frankopani, Zagreb 1901.). Istraživanje plemićkih obitelji dobiva novi zamah devedesetih godina 20. stoljeća, kada brojne plemićke obitelji i rodovi postaju tema magistarskih radova i 
Bruno Škreblin: Uloga obiteljskih veza u formiranju gradske elite zagrebačkog Gradeca

Zb. Odsjeka povij. znan. Zavoda povij. druš. znan. Hrvat. akad. znan. umjet., 34 (2016), str. 39-87

Tako je historiografsko istraživanje obitelji u kontekstu društvenih elita - plemićkih ili gradskih - privuklo povjesničare mnogo prije nego što su uslijedili specijalistički znanstveni radovi o obitelji u srednjem vijeku iz sociološkog, antropološkog, ekonomskog ili demografskog kuta, odnosno prije nego što se sedamdesetih godina 20. st. istraživanje obitelji pojavilo kao zasebna specijalistička grana u historiografiji ( $\mathrm{Hi}$ story of the family). ${ }^{2}$ Znanstveno istraživanje obitelji ujedno je pridonijelo razvoju povijesne demografije, pravne povijesti i rodnih studija, ${ }^{3}$ tako da suvremeno povijesno istraživanje obitelji danas uvelike podrazumijeva interdisciplinarnost i poznavanje socioloških, antropoloških i demografskih pristupa, pravnih običaja i normi, kao i poznavanje književnih djela i ostataka materijalne kulture. ${ }^{4}$

S obzirom da je pripadnost nekom važnom rodu ili značajnoj obitelji i u urbanim sredinama osiguravao društveni ugled i status, suvremena je znanstvena analiza gradskih elita nezamisliva bez ujedno i analize obiteljskog porijekla njenih pripadnika. U hrvatskoj urbanoj historiografiji ta je tema dosad najviše istraživana na području dalmatinskih komunalnih gradova, posebice Dubrovnika i Zadra. ${ }^{5}$ Spomenuta istraživanja Zdenke Janeković-Römer, odnosno Zrinke Nikolić Jakus, predstavljaju važan teorijski i metodološki okvir za uvid u problematku obitelji u srednjem vijeku, iako valja istaknuti da je zagrebački Gradec pripadao srednjoeuropskom (ili kontinentalnom) sustavu gradova u kojima, za razliku od dalmatinskih odnosno mediteranskih, ne postoji zatvorena skupna građana (patricijat) koja u kasnom srednjem vijeku koncentrira svu vlast u svojim rukama. To naravno ne mijenja činjenicu da su i u kontinentalnim gradovima obiteljske i rodbinske veze imale

disertacija ili monografija, a rezultati tih istraživanja često su popraćeni i genealogijama. Pregled tih radova do 2006. vidi u: Damir Karbić, Plemstvo-definicija, vrste, uloga, Povijesni prilozi, god. 25, br. 31, Zagreb 2006., str. 11-21.

2 Smatra se da je začetnik istraživanja srednjovjekovne obitelji bio poznati francuski povjesničar Marc Bloch u svom djelu La société féodale, La formation des liens de dépendance, les classes et le gouvernement des hommes, Paris 1949. (hrvatski prijevod: Feudalno društvo, Zagreb, 1958.). Ovdje ćemo se samo osvrnuti na dio strane literature, novijeg datuma ili veće važnosti u kontekstu tematike ovog rada. Općenito o ulozi i značenju obitelji vidi: Michael Mitterauer - Reinhard Sieder, The European Family: Patriarchy to Partnership from the Middle Ages to the Present, Oxford 1983., str. 1-5. Jedan od najpoznatiji suvremenih istraživača obitelji je David Herlihy, Women, Family and Society in Medieval Europe, Oxford 1995. Isti autor poznat je po svom istraživanju toskanskih obitelji: David Herlihy - Christine Klapisch-Zuber, Tuscans and their Families. A study of the florentine catasto of 1427, New Haven - London 1985. Jacques Heers istraživao je srednjovjekovnu obiteljsku strukturu i formiranje klanova u europskim urbanim sredinama: Jacques Heers, Family clans in the Middle Ages: A study of political and social structures in urban areas, Amsterdam - New York - Oxford 1977. Za istraživanje ove teme od velike su koristi bili radovi u zborniku: Generations in towns: Succession and success in pre-industrial urban societies, ur. Finn Einar Eliassen - Katalin Szende, Cambridge 2009.

3 Finn Einar Eliassen - Katalin Szende, Generations in Towns: Introduction, u: Generations in Towns, str. 4-5.

4 Marija Karbić, Obitelj u gradskim naseljima srednjovjekovne Slavonije: 13.-16. stoljeće, neobjavljeni magistarski rad, Zagreb 2001., str. 9.

5 Zdenka Janeković Römer, Rod i grad: dubrovačka obitelj od XIII. do XV. stoljeća, Zagreb 1994.; Ista, Rodbinski odnosi u dalmatinskom društvu XIII. i XIV. stoljeća, Historijski zbornik, god. 45, br. 1, Zagreb 1992., str. 179-194; Zrinka Nikolić, Rođaci i bližnji: Dalmatinsko gradsko plemstvo u ranom srednjem vijeku, Zagreb 2003. 
Bruno Škreblin: Uloga obiteljskih veza u formiranju gradske elite zagrebačkog Gradeca

Zb. Odsjeka povij. znan. Zavoda povij. druš. znan. Hrvat. akad. znan. umjet., 34 (2016), str. 39-87

vrlo važnu ulogu u formiranju gradske elite, ali osim nepostojanja patricijata, postojale su i još neke različitosti, o čemu će biti riječi dalje u tekstu. Problematici srednjovjekovne obitelji u kontinentalnom sustavu gradova u domaćoj se historiografiji bavila Marija Karbić u neobjavljenoj magistarskoj disertaciji te više znanstvenih radova, a osim Gradeca, njezin fokus uključio je Varaždin i Ilok u onoj mjeri u kojoj su to dozvoljavali izvori. ${ }^{6}$ Naravno, kao prvog istraživača koji se bavio određenim pitanjima vezanim uz obitelj na Gradecu, možemo označiti Ivana Krstitelja Tkalčića, priređivača serije povijesnih izvora za Gradec. ${ }^{7}$ U svojim opsežnim uvodnim tekstovima, Tkalčić je, na temelju izvornih podataka opisao mnoge imovinsko-pravne odnose u obitelji, nasljedno pravo, te položaj žena i djece. Tkalčićevo objavljivanje izvora rezultiralo je i prvom studijom posvećenoj jednoj gradskoj obitelji. ${ }^{8}$ Za istraživanje povijesti obitelji na Gradecu važni su i radovi Vladimira Bedenka koji je identificirao mnoge rodbinske veze analizirajući promjene vlasništva nad nekretninama ili principe nasljeđivanje istih ${ }^{9}$ a nisu mogla biti zaobiđena djela pravnih povjesničara, ${ }^{10}$ kao niti noviji radovi koji obrađuju neku konkretnu obitelj ili pak više međusobno povezanih gradskih obitelji na zagrebačkom Gradecu. ${ }^{11}$

Međutim, među historiografijom valja se još posebno osvrnuti na radove Nade Klaić, zbog toga što je ona prva analizirala obiteljske veze članova gradečkog

6 Za magisterij, vidi bilj. 4. Za kontekst ovog istraživanja važniji su i sljedeći radovi iste autorice: Marija Karbić, Obitelj Bole: istaknuti predstavnici de lingua Theutonicorum na zagrebačkom Gradecu u 14. i 15. stoljeću, Godišnjak njemačke narodnosne zajednice - DG Jahrbuch, sv. 14, Osijek 2007., str. 11-19; Ista, Što znamo o nezakonitoj djeci u gradskim naseljima u međurječju Save i Drave tijekom srednjeg vijeka?, Scrinia slavonica, sv. 2, Slavonski Brod 2002., str. 168-177; Ista, The 'Illicit Love' in Medieval Slavonian Cities, u: Love, Marriage and Family Ties in the Middle Ages, ur. Isabel Davis - Miriam Müller - Sarah Rees Jones, International Medieval Research, sv. 11, Turnhout 2003., str. 331-340; Ista, Proximi et consanguinei. Prilog poznavanju značenja rodbinskih veza u gradskim naseljima međurječja Save i Drave tijekom srednjeg vijeka, u: Raukarov zbornik. Zbornik u čast Tomislava Raukara, ur. Neven Budak, Zagreb 2005., str. 245-262; Ista, Women and Property in Medieval Slavonian Towns, u: Towns and Cities of the Croatian Middle Ages: Authority and Property, ur. Irena Benyovsky Latin - Zrinka Pešorda Vardić, Zagreb 2014., str. 439-454.

7 Povjestni spomenici slob. kralj. grad. Zagreba. Monumenta historica liberae regiae civitatis Zagrabiae, sv. 1-11, prir. Ivan Krstitelj Tkalčić, Zagreb 1889.-1905. (dalje: MCZ).

8 Bogoljub Krnić, Ivan Pastor Zagrepčanin, politički agent kralja Ferdinanda I., Rad JAZU, knj. 201, Zagreb 1914., str. 67-174.

9 Vladimir Bedenko, Zagrebački Gradec: Kuća i grad u srednjem vijeku, Zagreb 1989.; Isti, Društvo i prostor zagrebačkog Gradeca, u: Zagrebački Gradec 1242.-1850., ur. Ivan Kampuš - Lujo Margetić - Franjo Šanjek, Zagreb 1994., str. 37-49.

10 Magdalena Apostolova-Maršavelski, Iz pravne prošlosti Zagreba (13-16. stoljeće), Zagreb 1998.; Ista, O oporučnoj slobodi u zagrebačkom Gradecu - po Zlatnoj buli i kasnijoj praksi, u: Zagrebački Gradec, str. 91-101.

11 Bruno Škreblin, Obitelj Šafar - iz života jedne njemačke obitelji, Godišnjak njemačke zajednice - DG Jahrbuch, sv. 16, Osijek 2009., str. 83-100; Isti, Nijemci na Gradecu sredinom i u drugoj polovici 15. stoljeća, Godišnjak njemačke zajednice - DG Jahrbuch, sv. 17, Osijek 2010., str. 33-54; Isti, Urbana elita zagrebačkog Gradeca u 15. i početkom 16. stoljeća, u: Mestne elite v srednjem in zgodnjem novem veku med Alpami, Jadranom in Panonsko nižino. Urban Elites in Middle and Early Modern Age between the Alps, the Adriatic and the Pannonian Plain, Zbirka Zgodovinskega časopisa, sv. 42, Ljubljana 2011., str. 308-332; Isti, Pripadnici plemićke zajednice iz Klokoča na zagrebačkom Gradecu u 15. stoljeću: Primjer uloge sitnog plemstva u formiranju urbanih elita, u: Ascendere historiam: Zbornik u čast dr. Milana Kruheka, ur. Marija Karbić - Hrvoje Kekez - Ana Novak - Zorislav Horvat, Zagreb 2014., str. 67-80. 
Bruno Škreblin: Uloga obiteljskih veza u formiranju gradske elite zagrebačkog Gradeca

Zb. Odsjeka povij. znan. Zavoda povij. druš. znan. Hrvat. akad. znan. umjet., 34 (2016), str. 39-87

magistrata, prvo u radu "O firentinskoj koloniji", a potom u monografiji Zagreb u srednjem vijeku. ${ }^{12}$ Uvidjevši više rodbinskih poveznica između građana u magistra$\mathrm{tu}$, autorica je zaključila da bi se moglo govoriti i o nepotizmu u gradskoj upravi u 15. stoljeću. ${ }^{13}$ Nepotizam u današnjem smislu ima isključivo negativnu konotaciju, pa to nije najbolji termin za definiranje ili opis srednjovjekovnog gradskog magistrata, čega je bila svjesna i Klaić. Naime, nepotizam bi podrazumijevao postojanje ekskluzivnih obitelji i političku diskriminaciju onih koji ne participiraju u vlasti. Međutim, obnašanje vlasti u srednjovjekovnom gradu kontinentalnog tipa ionako je bilo rezervirano isključivo za punopravne građane - one koji su posjedovali civitet, što znači da su posjedovali vlastitu nekretninu i plaćali određenu pristojbu. Takvih, pravih građana bilo je tek nekoliko stotina, a s obzirom na praksu ženidbenih povezivanja unutar istog statusnog kruga, o čemu će još biti riječi u tekstu, kao i činjenicu da je Gradec relativno mali grad, ne treba čuditi činjenica da su mnogi pripadnici magistrata bili rodbinski povezani. Upravo je namjera ovog rada prvo faktično utvrditi i analizirati rodbinske odnose između članova gradskog magistrata, glavnog upravno-političkog tijela na zagrebačkom Gradecu, a zatim znanstveno analizirati rodbinske veze kao čimbenik društvenog uspjeha i formiranju urbane elite $u$ srednjovjekovnom gradu.

\section{Glavni problemi i metodologija}

Identifikacija rodbinskih odnosa moguća je samo ako imamo valjanih podataka u izvorima. Kasnosrednjovjekovni izvori i nisu baš zahvalna građa po tom pitanju, jer iako ima dosta primjera formiranja pravih prezimena, još je uvijek najčešća rodbinska odrednica navođenje imena oca uz osobno ime npr. Petar, sin Jurja (Petrus filius Georgii). Također, u ovom razdoblju ne postoje matične knjige, a sačuvanih oporuka iz kojih se često najbolje vide sve rodbinske veze na Gradecu vrlo je malo, pa je najčešće nemoguće rekonstruirati daljnje rodbinske odnose. Tako smo osuđeni na gradske izvore koji rodbinsku odrednicu za nekog građanina daju praktički tek usput fokusirajući se uglavnom na one najbliže, obiteljske veze. Osim toga, u mnogim se slučajevima ista osoba pojavljuje upisana na različite načine, ili se pak javlja samo po imenu, što ponovno otežava sigurnost u identifikaciji ukoliko je ime učestalo. Primjerice, sredinom 15. st. na Gradecu žive dva Blaža koji su sinovi Pavla. Blaž, sin Pavla Čarantovića, te Blaž štacunar, sin Pavla, koji postaje sudac 1441. godine. S obzirom na to da oba Blaža žive u isto vrijeme, na prvi pogled bilo bi sasvim logično da je zapravo riječ o istoj osobi. Tek su njihovi različiti nasljednici uspjeli napraviti vidljivu razliku. Pogrešci lako može pridonijeti činjenica da su gradski notari imali običaj da gradskog suca u sastavima magistrata upisuju s imenom oca uz osobno ime,

12 Nada Klaić, O firentinskoj “koloniji” na zagrebačkom Gradecu potkraj 14. stoljeća, Balkanika. Radovi Instituta za balkanološke studije, sv. 13-14, Beograd 1982.-1983., str. 57-72; Ista, Zagreb u srednjem vijeku, Zagreb 1982.

13 N. Klaić, Zagreb, str. 222. 
Bruno Škreblin: Uloga obiteljskih veza u formiranju gradske elite zagrebačkog Gradeca Zb. Odsjeka povij. znan. Zavoda povij. druš. znan. Hrvat. akad. znan. umjet., 34 (2016), str. 39-87

a dok ranije u magistratu ili gradskim dokumentima može imati drugačiju identifikacijsku odrednicu. Tako je sudac 1447. u sazivu magistrata Andrija, sin Mihaela, znan još i kao Andrija Latinus ili Andrija Vlah. Sudac iz 1419. u sazivu je magistrata naveden kao Ivan (Johannes), sin Nikole, a u drugim dokumentima češće se upisuje kao Ivan Zigeštak. Može se zaključiti da notar, nažalost, u slučaju dvojice Blaža nije smatrao potrebnim jače istaknuti razliku između njih, kao što je neki njegov prethodnik to činio u slučajevima dva Marka koji su bili sinovi Mikeča krajem 14. stoljeća. Oni su se često upisivali i uz ime djeda. Tako je jedan bio Marko, sin Mikeča, sina Franje, a drugi Marko, sin Mikeča, sina Leonardovog. Osim dva Pavla, sredinom 15. st. na Gradecu su i dva Benedikta, koji su sinovi Mihaela. Sudac iz 1443. je Benedikt, sin Mihaela, a u isto vrijeme sve se češće spominje i Benedikt, sin suca Mihaela Sebastijana. Međutim, Sebastijanov sin nigdje se kasnije ne spominje kao judex ili condam judex nego isključivo kao juratus, što je dokaz da Benedikt, sin suca Mihaela Sebastijana, nije obnašao sudačku funkciju. Zbog toga je zasigurno točan stav Bedenka da je riječ o krojaču Benediktu Škrinjariću. ${ }^{14}$ Može se još spomenuti da je u isto vrijeme često na prisežničkoj funkciji bio i Benedikt, sin Gyuana, tako da otprilike $\mathrm{u}$ isto vrijeme postoje tri politički aktivna građanina s istim imenom, od čega dvojica imaju i isto ime oca. Ilustrativan je i slučaj sinova Angela (filii Angeli) iz 14. st. koji su zastupnici u mađarskoj skupini i riječ je o trojici braće. Spominju se još 1363. kada u sporu sa zastupnikom zagrebačkog biskupa tvrde za sebe da su plemići zaladskog distrikta (nobiles nationes hungarice ... districtus de Zala). ${ }^{15}$ Jedan od Angelijevih sinova zvao se Petar, sin Grgura, što je navelo N. Klaić da zaključi da je jedan od sinova Angela bio i gradski sudac, odnosno da je spomenuti Petar identičan sa sucem iz 1393., Petrom Velikim (magnus), sinom Grgura. ${ }^{16}$ Ipak, nije riječ o članu obitelji Angelija jer se Petar magnus (ili longus) može pratiti u magistratu u slavenskoj skupini, a 1393. upravo je na Slavene bio red za sudačku funkciju. Također, biskupov popis izopćenih građana iz 1397. navodi Petra Velikog kao bivšeg suca. Međutim, tu zavrzlama ne prestaje jer od devedesetih godina 14. st. na Gradec dolazi i Pero (Petar), sin Angela iz Firence. U radu "Etničke i političke skupine", slično kao i Nada Klaić, poistovjetio sam te dvije obitelji - mađarske i firentinske Angelijeve ponovno metodom vjerojatnosti, odnosno da $u$ isto vrijeme $u$ jednom manjem gradu vjerojatno ne postoje dva građanina, pripadnika gradske elite s istim osobnim imenom i imenom oca, jednako kao i slučaju dvojice Blaža, sina Pavla. ${ }^{17}$ Međutim, sasvim sigurno Angelijevi iz Zaladskog distrikta ne mogu biti identični Angelijevima iz Firence, odnosno ponovno je riječ o pukoj slučajnosti. Sve to govori o složenosti postupka identifikacije. Zaključno, ne postoji neki jasan model ili jednostavna formula po kojoj bi se identificirali isti građani u magistratu, nego se svaki slučaj mora zasebno razmatrati,

${ }_{14}$ Bedenko, Zagrebački Gradec, str. 57.

15 MCZ 4, str. 279

16 N. Klaić, Zagreb, str. 257.

17 Bruno Škreblin, Etničke i političke skupine u srednjovjekovnom gradu: Primjer gradečkih lingui, Povijesni prilozi, god. 27, br. 35, Zagreb 2008., str. 113. 
Bruno Škreblin: Uloga obiteljskih veza u formiranju gradske elite zagrebačkog Gradeca

Zb. Odsjeka povij. znan. Zavoda povij. druš. znan. Hrvat. akad. znan. umjet., 34 (2016), str. 39-87

a identična imena koja se javljaju u isto vrijeme treba ipak uzeti s dozom opreza, osobito ako je riječ o učestalim kršćanskim imenima. $S$ obzirom da bi takav pristup prema svakom članu magistrata, zapravo čak i prema svakom sucu, zauzeo cijeli prostor ovog rada, ovdje je najveća pozornost pridana sucima, koji su uostalom isto tako prethodno bili vijećnici i jurati, te nekim prisežnicima i vijećnicima koji nisu postali suci, ali ih je lako identificirati zbog njihovog specifičnog ili lako prepoznatljivog imena.

Još je potrebno dodatno naglasiti isti problem kod identifikacije žena koje su udane za članove gradske elite. Nažalost, notar nije svaki put zabilježio tko je otac žene koja je udana za pojedinog građanina, nego tu osobu sad identificira putem muža, npr. Agatha uxor Jacobi. Tako ne znamo uvijek iz koje obitelji dolazi žena člana gradske elite. Osim toga, identifikaciju dodatno otežava činjenica da velika većina žena ima identična imena, poput Margareta, Katarina i Jelena. Ipak, podaci s kojima raspolažemo dovoljni su kako bi stekli određeni uvid u rodbinsku povezanost gradečke gradske elite.

Za glavnu metodologiju u radu odabran je prosopografski pristup, odnosna grupna ili kolektivna biografija, u ovom slučaju gradečkih građana koji se nalaze u magistratu. Prosopografija je kvantitativna metoda koja se u zadnjih nekoliko desetljeća etablirala kao jedna od boljih znanstvenih metoda za istraživanje kompleksnijih sustava kao što su u srednjem vijeku bili gradovi ili pak crkvene institucije. U hrvatskoj historiografiji začetak prosopografije možemo vidjeti još u spomenutom radu Nade Klaić "O firentinskoj koloniji", a u novije vrijeme i drugi hrvatski povjesničari koriste prosopografsku metodu.$^{18}$ Upotrebom prosopografske metode $\mathrm{u}$ istraživanju urbanih elita analiziraju se prikupljeni podaci iz izvora, te se tako dobivaju zajedničke pozadinske karakteristike nekih povijesnih aktera. ${ }^{19}$ Glavni podaci koji ulaze $\mathrm{u}$ prospografsku analizu su: političke funkcije pojedinog građanina, društveni odnosi - prije svega ženidbene veze ali i ostale rodbinske, prijateljske i poslovne veze te pokazatelji ekonomske moći pojedinog građanina prije svega u vidu vlasništva nad različitim vrstama posjeda. Naravno, za potrebe ovog rada uzimani su samo političke funkcije kao pokazatelj pripadnosti gradskoj eliti te podaci o ženidbenim odnosno rodbinskim vezama.

18 Marko Jerković, Djelovanje zagrebačkog Kaptola i njegovih kanonika u 14. stoljeću, neobjavljena doktorska disertacija, Zagreb 2011.; Bruno Škreblin, Urbana elita zagrebačkog Gradeca: od sredine 14. do početka 16. stoljeća, neobjavljena doktorska disertacija, Zagreb 2015.

19 Više o prosopografskoj metodi u: Charlotte Carpenter, The Formation of Urban Élites: Civic Officials in Late Medieval York (1476-1525), neobjavljena doktorska disertacija, York 2000. 
Bruno Škreblin: Uloga obiteljskih veza u formiranju gradske elite zagrebačkog Gradeca Zb. Odsjeka povij. znan. Zavoda povij. druš. znan. Hrvat. akad. znan. umjet., 34 (2016), str. 39-87

\section{Rodbinska povezanost $\mathbf{u}$ gradskom magistratu zagrebačkog Gradeca. Primjeri velikih obitelji}

\section{Obitelj de Spinal-Bonioli-Cion}

Radi lakšeg praćenja, metodološki smo prvo izdvojili deset obitelji kod kojih se mogu identificirati različite vrste rodbinskih veza u dužem periodu. $U$ prvom redu spomenut ćemo tri obitelji čiji su pripadnici bili ženidbeno povezani. Zanimljivo je da su sve bile talijanskog porijekla. Prvi pripadnik obitelji Gerin, koja se u prvo vrijeme često javlja s prefiksom ser, zbog čega se njihovo prezime i javlja u obliku Sirgerini (Syrgirini), bio je Nikola, spomenut još 1317. godine. Te godine Nikola prima u zalog neku zemlju od turopoljskih plemića iz Mlake..$^{20}$ Sljedeći poznati član te obitelji bila su braća Andrija i Nikola koji su kupili Gilionovu palaču na Gradecu, oko čega su se sporili s banom Mikcem. ${ }^{21}$ Nasljednici Andrije i Nikole kasnije se često u izvorima javljaju samo kao sinovi Gerina (filii Gerini), zbog čega je otežana precizna rekonstrukcija njihove obiteljske strukture, odnosno nije posve sigurno koliko je zapravo bilo potomaka te braće. Najčešće se spominju braća Andrija i Gerin koji su, sudeći po jednom dokumentu, bili sinovi Nikole Gerina. ${ }^{22}$ Gerin se najčešće spominjao kao vlasnik gradskog kupališta (balneator) čiji je prvi vlasnik bio Mafeo Biondo iz Venecije, a kupalište je Gerin dobio rodbinskim vezama vjerojatno kao dar svoje žene Beniche, kćerke Mafea Bionda iz Venecije. ${ }^{23}$ Osim te veze, Gerini su bili povezani i s Antunom, sinom Vide, odnosno Gerin je bio i očuh Antuna Vide, što znači da je nakon smrti Beniche oženio majku Antuna Vide. ${ }^{24}$ Tek se u drugoj polovini 14. st. počinje javljati i njihovo prezime de Spinal. ${ }^{25}$

Druga braća talijanskog porijekla bili su Marko i Petar Bonioli. I dok o Petru ne saznajemo mnogo, Marko se više puta spominje $u$ izvorima, a njegova je najviša funkcija bila ona prisežnička. Markov zet bio je Luka, sin Jakova iz Apulije, kojeg će po Markovom prezimenu prozvati Bonioli. ${ }^{26}$ Druga žena Lukina bila je Regina, kći Gerina i Beniche, čime je Luka bio rodbinski povezan sa dvije značajne gradečke obitelji u drugoj polovini 14. stoljeća. ${ }^{27}$ Luka je imao sina Ivana kojeg vidimo na funkciji prisežnika do njegove smrti 1413., kćerku Lucku udanu za nekog Petra kaštelana, dakle zasigurno pripadnika sitnog plemstva, te još jednu kćer, Benichu koja je bila udana za firentinskog trgovca Ciona, sina Ivanovog. ${ }^{28}$ Nakon smrti Beniche, Cion se ponovno oženio Katarinom, sestrom suca Marina Klarića iz Senja. ${ }^{29}$ Iz prvog bra-

\footnotetext{
MCZ 1, str. 117.

21 MCZ 1, str. 137-139.

$22 \mathrm{MCZ} 4$, str. 32.

MCZ 1, str. 455-457; MCZ 9, str. 63.

MCZ 4, str. 286

MCZ 4, str. 149.

MCZ 4, str. 197.

MCZ 9, str. 11.

8 MCZ 9, str. 101.

29 MCZ 9, str. 329
} 
Bruno Škreblin: Uloga obiteljskih veza u formiranju gradske elite zagrebačkog Gradeca Zb. Odsjeka povij. znan. Zavoda povij. druš. znan. Hrvat. akad. znan. umjet., 34 (2016), str. 39-87

ka Cion je imao kćerku Doroteju, koja se udala za Jurja Oxlyna iz Brežica, prilično uglednog plemića s područja Carstva, a iz drugog braka sina Tomu. ${ }^{30}$ Tomina djeca Juraj, Lodovik i Doroteja posljednji su članovi te obitelji koji se mogu identificirati, no čini se da nisu bili politički aktivni. ${ }^{31}$

\section{Obitelj de Medzo}

Druga veća obitelj talijanskog podrijetla bila je obitelj sinova Donata de Medzo. Vjerojatno je također riječ o doseljenicima s prostora sjeverne Italije, iako je nekim povjesničarima to prezime sugeriralo francuski Metz. ${ }^{32}$ Najugledniji član te obitelji bio je zlatar Petar Donat (filius Donati), što zaključujemo po tome jer je 1368. bio sudac, iako je moguće da je Petar tu funkciju već ranije obnašao. Obitelj de Medzo bila je u rodbinskim odnosima s obitelji Pintikachy, dakle vjerojatno jednom drugom talijanskom obitelji, odnosno Donatus se navodi kao proximus Pintikachy. ${ }^{33}$ Sudeći po Bedenkovoj rekonstrukciji posjeda, Franciska, kći Gyuana Donatija, naslijedila je posjed svog strica, suca Petra Donata. ${ }^{34}$ Franciska je bila udana za trgovca Filipa, sina Marka, s kojim je imala sina Žigmunda, jurata u latinskoj skupini, a nakon Filipove smrti preudala se za Ivana Gračina. ${ }^{35}$ Ivan Gračin imao je još dvije kćerke: Elizabetu koja je bila udana za Petra, sina Grgura Angelijevog, prisežnika iz mađarske skupine, ${ }^{36}$ a još se spominje i Marica, udana za Andriju, sina Antuna. ${ }^{37}$ Moguće da su spomenute bile iz prvog Ivanovog braka. Kći Ivana i Franciske, Lucija, bila je pak udana za Ivana Zigeštaka, suca 1419., a nakon njegove smrti preudaje se za Mihaela, sina Andrije, koji je bio sudac u Božjakovini. ${ }^{38}$ Postoje još podaci i o sestri Ivana Zigeštaka, Ceciliji koja je imala dva sina iz dva braka - s Gallom je imala sina Petra zvanog Pentera, jurata, a s juratom Mihaelom Ortphom, Stjepana suca iz 1433. ${ }^{39}$ Uglavnom, to su posljednji članovi koji se mogu dovesti u vezu s obitelji de Medzo, iako već Cecilijini nasljednici nisu više u direktnoj obiteljskoj vezi s obitelji de Medzo. Petar Pentera imao je četiri sina: Valentina, Pavla, Gala i Mihaela, no oni se ne mogu više jasno identificirati u gradskom magistratu, što kao i slučaju Cionovih nasljednika vjerojatno znači da oni nisu igrali značajnu ulogu u političkom životu Gradeca. ${ }^{40}$

30 MCZ 9, str. 220. Na Gradecu Dorotejin muž se naziva Georgius Oxlyn de Reyn, no u slovenskoj je historiografji njegovo ime zabilježeno kao Jörg Öcssel (vidi: Tone Ravnikar, Mestne elite v srednjeveških Brežicah in Sevnici, u: Mestne elite v srednjem in zgodnjem novem veku, str. 250-263).

31 MCZ 9, str. 340-341.

32 Neven Budak - Karolina Kanižaj - Svjetlana Vorel, Kolonije stranaca na Gradecu u 14. st., Izdanja $H A D$, sv. 17, Zagreb 1996., str. 82.

33 MCZ 4, str. 35.

34 Bedenko, Društvo i prostor, str. 44-45.

35 MCZ 9, str. 91, 115

36 MCZ 6, str. 157-158.

37 MCZ 9, str. 350.

38 MCZ 9, str. 226.

39 MCZ 9, str. 237, 253.

40 MCZ 7, str. 36. 
Bruno Škreblin: Uloga obiteljskih veza u formiranju gradske elite zagrebačkog Gradeca

Zb. Odsjeka povij. znan. Zavoda povij. druš. znan. Hrvat. akad. znan. umjet., 34 (2016), str. 39-87

\section{Obitelj Pere, sina Angela iz Firence}

Peroviće možemo označiti kao treću veliku obitelj koja se može pratiti u više generacija. Prvi poznati član bio je Pero, sin Angela iz Firence koji je na Gradec stigao početkom devedesetih godina 14. st., a do početka 15. st. obnašao je i dužnost prisežnika. Kako je već naznačeno, obitelj Pere iz Firence ne treba miješati s Petrom, sinom Angelija iz mađarske skupine. Pero je bio oženjen Margaretom, no za nju znamo tek da je bila kćerka neke domine Petrane, bez podrobnijih informacija o toj obitelji. ${ }^{41}$ Nakon Perine smrti Margareta se preudala za Brikcija, sina Benediktovog, koji je sudac 1427., dok je Brikcijev brat Juraj bio prisežnik. ${ }^{42}$ Sin Pere i Margarete zvao se Ivan, sudac 1434., od kojeg će se obitelj nazivati Perović.

Ivan Perović imao je najmanje tri sina i četiri ili više kćeri. Jedna njegova kći, Magdalena, udana je za Andriju krojača, sina Ivana iz Galberga, ${ }^{43}$ Ana za Ivana de Laad, ${ }^{44}$ Margareta za Nikolu krojača, sina Damjana iz Hruševice, klokočkog plemića, ali ona je umrla negdje 1456., jer se spomenuti Nikola navodi kao zet jednog drugog građanina. ${ }^{45}$ Međutim, 1480. u izvorima se opet pojavljuje Margareta, kći Perovića, kao redovnica samostana u Pečujskoj biskupiji. ${ }^{46}$ Nije bilo moguće utvrditi je li ovdje riječ o pogrešci, odnosno zamjeni imena Margareta za Magdalenu, što ne bi bio prvi slučaj, ili je Ivan dobio još jednu kćer nakon smrti Margarete, koju je ponovno nazvao Margareta. Slične nedoumice postoje i oko Perovićeve kćerke Katarine. Katarina se prvo navodi kao žena trgovca Blaža Ugrinovića iz Svetačja, ${ }^{47}$ koji umire prije 1462. , a potom Stjepana literata, ali se nakon toga navodi kao pokojna u dva dokumenta (1479.)..8 Međutim, potkraj stoljeća Katarina se zajedno sa sestrom Anom i djecom Tomom i Franjom de Bachan spominje u sporu s Dominikom Perovićem oko palače de Medzo koju je njihov otac Ivan stekao još 1437. godine. U dokumentima je upisano da su Toma i Franjo filii sororis Domkonis Perowych, pa doslovno ispada da je Ivan imao i dvije kćerke po imenu Katarina. ${ }^{49}$ Spomenuti zetovi Ivana Perovića, Nikola iz

${ }^{41}$ MCZ 9, str. 116.

42 MCZ 10, str. 9-10.

43 MCZ 7, str. 415 .

44 MCZ 8, str. 80.

45 MCZ 10, str. 125.

46 MCZ 8, str. 80.

47 MCZ 10, str. 165, 215

48 MCZ 7, str. 488, 489 .

49 MCZ 2, str. 507-508, MCZ 8, 113-115; 119. Benedikt Bachan bio je sakupljač poreza u zagrebačkoj županiji 1468. (MCZ 2, str. 320), a Baltazar medvedgradski kaštelan osamdesetih godina 15. stoljeća (MCZ 2, str. 421), kasnije i viceban Slavonije. Upravo je Baltazar otac Franje Bathánya koji je, prema Gézi Pálffyju, rođen 1479., međutim nije jasno je li možda riječ o tiskarskoj pogrešci jer se svugdje kao godina rođenja Franje Batthánya spominje 1497. (Géza Pálffy, Die Rolle der Familie Batthány in der Grenzverteidigung gegen die Osmanen im 16. und 17. Jahrhundret, Podravina: Časopis za multidisciplinarna istraživanja, god. 8, br 16, Koprivnica 2009., str. 73-88). Međutim, niti Pálffy ne navodi podrobnije rodbinske veze kasnosrednjovjekovnih Batthánya. U svakom slučaju, vezu između Perovića i obitelji Batthány trebalo bi još dodatno potkrijepiti arhivskim materijalom. 
Bruno Škreblin: Uloga obiteljskih veza u formiranju gradske elite zagrebačkog Gradeca Zb. Odsjeka povij. znan. Zavoda povij. druš. znan. Hrvat. akad. znan. umjet., 34 (2016), str. 39-87

Hruševice (Klokoča), krojač Andrija iz Galberga i Blaž Ugrinović iz Svetačja (Zinche) bili su gradski jurati.

Ivanovi sinovi zvali su se Juraj, Stjepan i Dominik koji je postao najugledniji budući da je u dva mandata gradski sudac, a bio je oženjen Klarom, udovicom Ivana Bolšaka mlađeg, odnosna sina suca Ivana iz Nürnberga. ${ }^{50}$ Dominik je imao sinove Gabrijela, Gašpara i kćer Anu, no osim samog spomena, ništa podrobnije ne saznajemo o njima, odnosno niti oni se ne mogu dalje identificirati kao pripadnici gradske elite. ${ }^{51}$

\section{Obitelj Sebastijana, sina Mladena}

Obitelj Sebastijana, sina Mladena, također predstavlja veliku građansku obitelj slavenskog porijekla koja se može pratiti u četiri generacije. Prvi njezin pripadnik na Gradecu, zlatar Sebastijan, bio je gradski sudac vjerojatno iz 70-ih godina 14. stoljeća. Sebastijan je bio oženjen Margaretom, sestrom Marka Francuza (Gallicus), što ukazuje da je Sebastijanova žena i majka Mihaela dolazila iz redova latinskog jezika. ${ }^{52}$ Nakon Sebastijanove smrti Margareta se preudala za Ivana Pavlovog, višestrukog gradskog suca u mađarskoj skupini. Iz Margaretinog prvog braka potječu sinovi Mihael i Leonard. Mihael se oženio Klarom, kćerkom Antuna, sina Vide, nakon što joj je umro prvi muž, prisežnik Zaharija Gallicus. ${ }^{53}$ Leonard se ženi kćerkom Mihaela Thara, sitnog plemića iz Paljane, no umire krajem 14. st. i ostavlja sina Blaža. ${ }^{54}$ Mihael je imao tri sina i četiri kćerke. Sinovi Benedikt, Marko i Juraj bili su nekoliko puta članovi gradskog magistrata, ali niti jedan od njih nije postao sudac. Međutim, s druge strane neki Mihaelovi zetovi uspjeli su postati suci, dok su dva zeta obnašala prisežničku funkciju. Jedan prisežnik bio je Leonard, sinu Henrika iz Bavarske, oženjen za Mihaelovu kćer Katarinu. ${ }^{55}$ Druga kći Magdalena (ili Jelena) bila je prva žena suca Valentina Šaronića, ${ }^{56}$ a preostale Barbara i Uršula bile su udane za gradske zlatare: Uršula za Pavla zlatara iz Kyus Jenowa, gradskog suca 1478. i 1484., ${ }^{57}$ a Barbara za prisežnika i zlatara Benedikta iz Baranje, ali se kasnije preudala za bivšeg gradskog suca Tomu Horvatina. ${ }^{58}$ Ipak, Mihaelov unuk Emerik, sin Marka, postat će sudac 1479 . godine. ${ }^{59}$ On je ujedno i posljednji član te obitelji koji se može identificirati.

\footnotetext{
50 MCZ 11, str. 16.

51 MCZ 11, str. 110-111.

52 MCZ 5, str. 73.

53 MCZ 10, str. 163

54 MCZ 6, str. 42

55 MCZ 10, str. 4.

56 MCZ 9, str. 319; MCZ 10, str. 34, 121.

57 MCZ 10, str. 100.

58 MCZ 10, str. 136; MCZ 11, str. 15, 43.

59 MCZ 8, str. 50.
} 
Bruno Škreblin: Uloga obiteljskih veza u formiranju gradske elite zagrebačkog Gradeca

Zb. Odsjeka povij. znan. Zavoda povij. druš. znan. Hrvat. akad. znan. umjet., 34 (2016), str. 39-87

\section{Obitelj Šaronić}

Druga velika obitelj slavenskog porijekla bili su Šaronići. Prvi član te obitelji na Gradecu bio je Mihael, sin Šimuna, plemića iz Gore. ${ }^{60}$ Ime njegove žene ne saznajemo, tako da ne znamo tko je bila majka Mihaelovog sina Valentina. Mihael je imao i brata Benedikta, ${ }^{61}$ dok se ne može utvrditi konkretna rodbinska povezanost Mihaela i nekog Ivana Šaronića, koji je vijećnik 1419.62 Valentin će pet puta obnašati sudačku funkciju i, kako je već spomenuto, prvo je bio oženjen Magdalenom ili Jelenom (Elena Jelka vocata), kćerkom Mihaela Sebastijana s kojom je imao sina Mihaela, a potom s Klarom, zvanom Gašparina s kojom je imao sinove Dominika literata, Jurja, Marka, Valentina, te još dvije kćerke, Katarinu i Doroteju. ${ }^{63}$ Ipak, samo Mihalea Šaronića jasno možemo identificirati kao člana gradskog magistrata, ujedno kao i posljednjeg člana te obitelji kojeg možemo identificirati kao politički aktivnog u gradskom magistratu, iako se Šaronići još spominju u izvorima. Tako izvori spominju i Mihaelovog sina Jurja koji je bio otišao iz Gradeca u Ilok. ${ }^{64}$ Ivan Šaronić, sin Dominika, dakle četvrta generacija Šaronića, spori se s Emerikom Therekom početkom 16. st. oko kuće i zemlje njegovog djeda Valentina. ${ }^{65}$ Vrlo je moguće da je upravo spomenuti Ivan identičan s plemićem Ivanom Šaronićem iz Kosnice koji je u 16. st. bio na dužnosti podžupana i plemićkog suca. ${ }^{66}$

\section{Obitelj Šafar-Gyuan}

Šafari su također posjedovali plemićki status, ali su živjeli gradskim životom. Petar, sin Petra Šafara, jurat je 1398., a sudac 1405. i 1413. godine. Poznato je da je Petar imao i brata Stjepana koji se nalazi u magistratu 1413. kao vijećnik. Petar je bio u srodstvu s obitelji firentinskog trgovca Gyuana, sina Benediktovog, jer je Benedikt, sin Gyuana, spomenut kao Petrov nećak. ${ }^{67} \mathrm{No}$, ne znamo točno tko je bila majka Petrovih sinova, Andrije, Petra zvanog Muž (Moxa) i Jakova jer se ime Petrove prve žene ne spominje. Petrova druga žena bila je Katarina, udovica Žigmunda, sina Marka, koju smo već spomenuli kod obitelji de Medzo. Andrija je bio oženjen Agnezom, kćerkom Klementina Pravdića, i jedini je od Šafarovih sinova uspio postati sudac, no

60 Njegovo ime, kao i plemićka titula spominje se u spisu remetskih pavlina: Mater Amabilis Maria Miraculosa Virgo Remetensis, Arhiv HAZU, Zbirka kodeksa, sign. II. d.104.

61 MCZ 6, str. 105

62 MCZ 6, str. 62.

63 MCZ 10, str. 270-271.

${ }^{64}$ MCZ 11, str. 107. U tom dokumentu iz 1519. Mihael je proglašen nekadašnjim sucem (olim senioris judicis), međutim u sastavima magistrata koji su u to vrijeme dobro očuvani, barem što se sudaca tiče, takvog podatka nema.

65 MCZ 8, str. 169-172.

66 MCZ 12, str. 119, 135. Vjerojatno je riječ o današnjoj Maloj Kosnici, a u popisu sela i stanovnika šćitarijevske župe u Kosnici spominje se i "knez Ivaniš Šaronić". Vidi: Zoran Ladić - Goran Budeč, Glagoljska bilježnica Šćitarijevskog župnika od 1524. do 1526. godine. Prilog proučavanju crkvenog i seoskog života u zagrebačkoj okolicu u ranom novom vijeku, Zbornik Odsjeka za povijesne znanosti Zavoda za povijesne i društvene znanosti Hrvatske akademije znanosti u umjetnosti, sv. 29, Zagreb 2011., str. 170.

67 MCZ 6, str. 38-39. 
Bruno Škreblin: Uloga obiteljskih veza u formiranju gradske elite zagrebačkog Gradeca

Zb. Odsjeka povij. znan. Zavoda povij. druš. znan. Hrvat. akad. znan. umjet., 34 (2016), str. 39-87

umire oko 1428. bez djece. ${ }^{68}$ Jakov je prvo bio oženjen Magdalenom, kćerkom spomenute Katarine i Žigmunda, ${ }^{69}$ a nakon njezine smrti s nekom Uršulom, no Jakovljeva djeca, Pavao i Elizabeta, nisu dugo poživjeli. ${ }^{70}$ Žena Petra mlađeg zvala se Skolastika i s njom je Petar imao trojicu sinova, Jurja, Ivana i Andriju te kćerku Katarinu, ali njih se više ne može identificirati kao pripadnike gradske elite. ${ }^{71}$

\section{Obitelj Bole}

U veće i značajnije gradečke obitelji svakako moramo svrstati i Bole, budući da su članovi te obitelji u tri generacije davale gradske suce. ${ }^{72}$ Prvi poznati član bio je Jakov, sin Pangracija, sudac 1379., a njegov sin Ivan također je barem jednom bio na sudačkoj funkciji (1391.). Ivan je imao trojicu sinova: Ivana zvanog Janko, Jakova i Nikolu, te kćerke o kojima ništa ne saznajemo. ${ }^{73}$ Jakov je sudac 1437., Janko je bio član magistrata, a Nikola je bio svećenik i rektor crkve sv. Marka. Nažalost, ženidbene veze u obitelji Bole uglavnom su nepoznate, Jakov Bole stariji bio je oženjen Skolastikom, no bez informacija o njezinoj obitelji, a njegov istoimeni unuk Jakov oženio je Agatu Pravdić, udovicu Andrije Šafara, iako je moguće da mu je to bila druga žena. ${ }^{74}$ Jakov je imao sinove Demetrija i Emerika, a Janko Petra i Luku te kćerku Margaretu, no oni se kasnije više ne mogu identificirati u dokumentima. ${ }^{75}$

\section{Obitelj Blaža, sina Pavla}

Obitelj štacunara Blaža, sina Pavla, suca iz 1441., također možemo označiti kao veću gradsku obitelj. ${ }^{76}$ Doduše Blažev društveni uspjeh nažalost nije moguće rekonstruirati jer nisu poznati njegovi roditelji kao niti obitelj njegove žene Margarete. Ipak, njegova obitelj pripada u veće i utjecajnije gradske obitelji sredine i druge polovine 15. stoljeća, jer se osim Blaža i njegovi nasljednici mogu uočiti kao pripadnici gradske elite. Njegove kćeri Katarina i Agata bile su udane za gradske jurate: Agata za Tomu Ivanovog, a Katarina za štacunara Matiju, sina Lodovika. ${ }^{77}$ Osim njih, Blaž je još imao kćerku Doroteu, te sinove Jurja, Matka i Mihaela, ali žene njegovih sinova nisu poznate. Od njih najčešće se spominje Miheael koji je bio učitelj slobodnih vještina (baccalaureus arte liberales), što znači da je studirao na nekom od srednjovjekovnih sveučilišta, a kao njegov zet još se navodi i bivši Perovićev zet, Nikola iz Klo-

${ }_{68}$ MCZ 6, str. 181-182.

69 MCZ 6, str. 217.

70 MCZ 7, str. 141

71 MCZ 10, str. 64. Detaljnije o toj obitelji vidi: Škreblin, Obitelj Šafar, str. 83-100.

72 Detaljnije o obitelji Bole, vidi: Karbić, Obitelj Bole, str. 11-19.

73 MCZ 9, str. 106.

74 MCZ 6, str. 399.

75 MCZ 6, str. 410.

76 MCZ 10, str. 445. Uvodno je upozoreno da se otprilike u isto vrijeme na Gradecu često spominje i Blaž Čarantović koji je isto tako sin Pavla i tek su različita imena njihove djece omogućila da uopće razlikujemo te građane.

77 MCZ 10, str. 170. 
Bruno Škreblin: Uloga obiteljskih veza u formiranju gradske elite zagrebačkog Gradeca Zb. Odsjeka povij. znan. Zavoda povij. druš. znan. Hrvat. akad. znan. umjet., 34 (2016), str. 39-87

koča, samo što nije poznato za koju je od Blaževih kćeri Nikola bio oženjen. ${ }^{78}$ Djeca Agate i Tome bili su Stjepan i Doroteja (Tolmanić) koja je bila udana za Jurja Vitkovića iz Modruša, dok se Katarina nakon smrti prvog muža kasnije preudala za Blaža Lazarina. ${ }^{79}$ Blaž Lazarin i Juraj Vitković pripadnici su gradske elite druge polovine 15 st., a suci su u dva navrata: Blaž je gradski sudac 1479. i 1485., a Juraj 1482. i 1490. godine.

\section{Obitelj Oprašnić}

Članove obitelji Oprašnić također možemo pratiti u tri generacije, ali za razliku od obitelji Bole, tek se u trećoj generaciji pojavljuje i gradski sudac iz te obitelji. Zapravo, može se reći da je literat Mihael Oprašnić, višestruki gradski sudac, bio jedan od najvažnijih i najmoćnijih gradečkih građana s početka 16 stoljeća. Njegov otac Antun mesar bio je članom magistrata, jednako kao i njegov djed, također mesar Juraj, pa je tako obitelj Oprašnić dobar primjer postupnog uzdizanja jedne gradečke obitelji na političko-društvenoj ljestvici. Mihaelov očuh bio je jurat postolar Gal, sin Andrije iz Dubice. ${ }^{80}$

\section{Obitelj Pastor}

Na kraju, spomenimo još i obitelj Pastor, iako veći dio njezinih članova zbog zadanog vremenskog perioda izlazi iz okvira ovog rada. Ipak, trgovac Ivan Pastor bio je jedan od najznačajnijih građana Gradeca s početka 16. stoljeća. Ivan zvani Gyuan (Sowan) postaje sudac 1512., a istu će funkciju obnašati još 1517. godine. Umire 1523. te ostavlja sinove Ivana i Gašpara te Anu udanu za Jurja Dobrovoljića i Kavku udanu također za nekog Jurja koji je oženivši Pastorovu kćerku prozvan Sovinović po nadimku Ivana Pastora. ${ }^{81}$ Nasljednike Ivana Gyauna Pastora možemo pratiti sve do druge polovice 16 st. Naime, turopoljski plemić i gradski sudac Matija Slatinski oženio je Barbaru, kćerku Jurja Dobrovoljića i Ane Pastor, a Matijin sin Juraj bio je egerski biskup. Unatoč dva sina i četiri kćeri loza Slatinskih izumrla je već s Matijinom djecom. ${ }^{82}$

\section{Ostale važnije rodbinske veze}

Naravno, pored gore istaknutih obitelji još je podosta primjera obiteljskih veza između pripadnika gradske elite. Prisežnik Perenchlo sin je suca Jakomela Quirina, ${ }^{83}$ a prisežnici i vijećnici bili su i sinovi suca Gyuana, Benedikt i Pavao, ali nisu postali

78 MCZ 10, str. 172; MCZ 7, str. 115.

79 MCZ 8, str. 80-81; MCZ 11, str. 2, 24, 66.

80 MCZ 10, str. 267.

81 MCZ 3, str. 223; MCZ 11, str. 110.

82 MCZ 13, str. 309; Nataša Štefanec, Grad na prvoj crti obrane, u: Povijest Grada Zagreba: Od prethistorije do 1918., ur. Ivo Goldstein - Slavko Goldstein, Zagreb 2012., str. 151.

83 MCZ 5, str. 335. 
Bruno Škreblin: Uloga obiteljskih veza u formiranju gradske elite zagrebačkog Gradeca

Zb. Odsjeka povij. znan. Zavoda povij. druš. znan. Hrvat. akad. znan. umjet., 34 (2016), str. 39-87

suci, ${ }^{84}$ jednako kao i Gašpar koji je sin suca Miklina. ${ }^{85}$ Gradečke obitelji Čarantović i Židovčić nisu davali gradske suce, ali su u najmanje dvije generacije davale zastupnike u gradski magistrat. ${ }^{86}$

Isto tako, još je mnogo slučajeva da se ugled stječe ili povećava afinatskim putem, odnosno ženidbenim povezivanjem s drugom obitelji ili s udovicama pokojnih građana. Tako je Ivan Vašaš zet suca Mikeča, sina Hencha, ${ }^{87}$ sudac Matija krojač zet je suca Andrije Šimunića ${ }^{88}$ Benedikt Škrinjarić zet je jurata Brikcija ribara, ${ }^{89}$ Antun, sin Tome zet je Vrbana jurata, ${ }^{90}$ Miklin je bio zet Andrije Puljanina (Pulyan), koji je pak bio sin prisežnika Petra Puljana. ${ }^{91}$ Blaž Stojimilić iz Šteničnjaka bio je oženjen za udovicu jurata Augustina Kusne, ${ }^{92}$ Andrija Latin, sin Mihaela, oženjen je za Skolastiku, udovicu jurata Jurja, sina Benediktovog, brata suca Brikcija kojeg smo spomenuli kod Perovićeve obitelji. ${ }^{93}$ Jakov Eberspeck oženio se Margaretom, udovicom spomenutog Brikcija ribara, a nakon njegove smrti Margareta se treći puta udala za Akacija, koji potom ulazi u magistrat. ${ }^{94}$ Antun Roth oženio je Katarinu, udovicu prisežnika Sebastijana Soldinara, pa se i on u magistratu upisuje kao Anthonius succesor Soldinar, iako je Sebastijan Soldinar imao sina Ivana..$^{95}$

\section{Prethodnici u magistratu - kontinuitet obitelji}

U ovoj analizi rodbinskih veza u prvom redu najvažnije je bilo utvrditi koji su prethodnici nekog građanina u magistratu. Tom analizom izvora za otprilike trećinu građana utvrđene su patrilinearne ili afinatske veze s ranijim članovima magistrata. Teško je utvrditi prethodnike u magistratu sudačkih obitelji u razdoblju od 1350. do kraja 14. st. jer nema dovoljno sačuvane građe.

Od 94 poznata suca u periodu od 1352. do 1525., za njih 34 može se utvrditi obiteljske ili ženidbene veze s prijašnjim članovima magistrata. ${ }^{96}$ Od toga broja tek 13 je patrilinearnih veza, dok su ostale ženidbene ili afinatske. ${ }^{97}$ Kod nekih građanina postojala su oba tipa veza s prethodnim članovima magistrata.

Kako bi lakše prikazali koji su suci bili obiteljski, rodbinski ili ženidbeno povezani u dužem vremenskom periodu, u tablici se nalazi i kratica ili oznaka obitelji

84 MCZ 6, str. 43, 272.

85 MCZ 6, str. 5.

86 Za Čaranotviće vidi: MCZ 6, str. 267, 343; za Židovčiće vidi: MCZ 6, str. 101; MCZ 7, str. 19.

87 MCZ 9, str. 23.

88 MCZ 7 str. 457

89 MCZ 9, str. 235

90 MCZ 7, str. 80.

91 MCZ 1, str. 374-375.

92 MCZ 10, str. 221

93 MCZ 10, str. 9.

94 MCZ 10, str. 163; MCZ 7, str. 220.

95 MCZ 10, str. 167.

96 Metodu određivanja približnog broja sudaca od 1350. do 1526. vidi u: Škreblin, Urbana elita zagrebačkog Gradeca, str. 38-41.

97 Vidi tablicu u prilogu. 
Bruno Škreblin: Uloga obiteljskih veza u formiranju gradske elite zagrebačkog Gradeca Zb. Odsjeka povij. znan. Zavoda povij. druš. znan. Hrvat. akad. znan. umjet., 34 (2016), str. 39-87

prema prvom ili najpoznatijem članu dotične obitelji. Za ovu svrhu, u obzir su uzimane samo one obitelji koje imaju najmanje dva člana na sudačkoj funkciji, odnosno koje su davale suce u više generacija. Primjerice, sudac Sebastijan, sin Mladena, prvi je poznati član te sudačke obitelji pa smo prema njemu nazvali sve njegove nasljednike uključujući i Ivana, sina Pavla, koji je nakon Sebastijanove smrti oženio njegovu udovicu. Uz spomenutog Ivana, pod Sebastijanove nasljednike ubrojili smo njegovog sina Mihaela i unuka Emerika, te zeta Pavla, sina Stjepanovog i Tomu, sina Andrije, premda Mihael više nije živ kada je došlo do sklapanja tih brakova. Ovdje nije ubrojen njegov zet Valentin Šaronić jer tu obitelj ipak vodimo prema Valentinovom ocu Mihaelu. O povezanosti obitelji Sebastijana i Šaronića još će biti riječi. Obitelj Perović iz metodoloških razloga vodimo prema Brikciju, s obzirom na to da je Brikcije prvi postao sudac, iako su Perovići bili ipak poznatiji članovi gradske elite. Iz istog razloga obitelj Šafar vodimo prema obitelji Gyuana, sina Benediktovog de Boncarnissa. Postavlja se pitanje trebamo li zetove u drugoj ili trećoj generaciji brojiti pod obitelj njihovih tastova ili bi oni trebali biti smatrani začetnicima novih obitelji? Isto pitanje vrijedi u slučajevima kada dolazi do ponovne ženidbe udovica. S obzirom na to da je ovdje namjera prvenstveno utvrditi kontinuitet određene obitelji kroz duži vremenski period, ne zanimaju nas toliko pravi biološki nasljednici nego i oni pravni jer su i takvi u najmanju ruku poboljšali svoj materijalni položaj naslijedivši imovinu ili dio imovine ženidbenim povezivanjem s drugom uglednom obitelji. Bez obzira na to što je Mihael Sebastijanić bio pokojan kada se njegova kći udala za zlatara Pavla, njegov je zet tom ženidbom svejedno dobio dio Mihaelove imovine. Osim same materijalne koristi, zetovi ili muževi udovica ženidbenim povezivanjem sa starijom uglednom obitelji podižu svoj status i ugled. Muževi udovica te zetovi pokojnih građana često se u izvorima spominju samo kao nasljednici (successor). Tako je Antun Roth, koji je oženio udovicu Sebastijana Soldinara, upisan kao succesor Soldinar jer mu je Katarina poklonila sve svoje posjede unatoč tome što je imala sina Ivana. Prisežnik Akacije (Achacius) je postao succesor Eberspeck jer je oženio udovicu tog bivšeg prisežnika Brikcija Ribara, a neki je Berlek successor Martini judicis, ${ }^{98}$ a sudac Fabijan Czaren navodi se pak kao heredes suca Konrada Rawsara. ${ }^{99}$

Na taj način može se identificirati 14 sudačkih obitelji iz čijih je redova kroz duže razdoblje dolazilo više sudaca, uzevši u obzir sve članove obitelji. ${ }^{100}$ To su Ligeriji (braća Marko i Petar), de Medzo (Petar Donat, Ivan Zigeštak, Stjepan, sin Mihaela Ortoflića), Hench (Mikeč, sin Hencha, Ivan Vašaš), Bole (Jakov, Ivan, Jakov mlađi), Sebastijani (Sebastijan, Ivan, sin Pavla, Marko, sin Mikeča Leonardovog, Mihael, sin Sebastijana, Toma, sin Andrije, Emerik, sin Marka, Pavao, sin Stjepana), Bonioli (Luka Bonioli, Cion, Marin Klarić), Gyuan-Šafar (Gyuan, Petar i Andrija Šafar),

98 MCZ 7, str. 383.

99 MCZ 6, str. 437

100 Ovdje se broje isključivo one sudačke obitelji koje su davale više od jednog suca. Primjerice, Martin Tomić je bio sudac više puta, no nije poznato je li neki kasniji sudac bio u srodstvu s Tomićem, niti je poznato je li Tomić imao nekog prethodnika na sudačkoj funkciji. 
Bruno Škreblin: Uloga obiteljskih veza u formiranju gradske elite zagrebačkog Gradeca Zb. Odsjeka povij. znan. Zavoda povij. druš. znan. Hrvat. akad. znan. umjet., 34 (2016), str. 39-87

Brikcije-Perović (Brikcije, sin Benedikta, Andrija Latin, Ivan i Dominik Perović), Šaronići (Mihael i Valentin Šaronić), Šimunić (Andrija, sin Šimuna, Matija, sin Marka), Blaž štacunar (Blaž štacunar, Blaž Lazarin, Juraj Vitković), Rawsar (Konrad Rawsar, Fabijan Czaren), Roth (Antun Roth, Ivan, sin Sebastijana Soldinara), Požegaj (braća Ivan i Marko).

Ovih 15 obitelji dalo je 40 sudaca koji su sudačku funkciju odrađivali u više od 70 mandata. ${ }^{101}$ Najviše ih je dala obitelj Sebastijana - čak 14 sudačkih mandata došlo je od pripadnika te obitelji, iza njih slijede Šaronići (7 mandata), a isti broj mandata imaju i nasljednici Boniolija, te Rawsara. Obitelj Sebastijana i Šaronića vodimo zasebno unatoč njihovoj rodbinskoj povezanosti jer poveznica između obitelji dolazi tek s Valentinom, ali je zato u obitelj Sebastijana ubrojen Toma, sin Andrije, premda nije sigurno da je Toma bio sudac nakon što se rodbinski povezao s tom obitelji, ili se s obitelji Sebastijana povezao tek poslije obnašanja sudačke funkcije.

Naravno, ovi su rezultati odraz sačuvanosti gradskih izvora. Vjerojatno je bilo još više građana na sudačkoj funkciji koji su imali obiteljske prethodnike u magistratu, ili su na neki način bili rodbinski povezani s nekim od prijašnjih sudaca, ali to nije moguće sa većom sigurnošću dokazati. ${ }^{102}$

\section{Rodbinski odnosi u pojedinačnom sazivu magistrata}

Svakako je zanimljivo vidjeti koliko je rodbinski povezanih građana bilo u pojedinačnom sastavu magistrata. Godine 1413. sudac je bio Petar Šafar, a među vijećnicima nalazimo i njegovog brata Stjepana. Kao zastupnici njemačkog jezika među vijećnicima se nalazi bivši sudac Miklin i njegov sin Gašpar, a među latinskim vijećnicima nalazi se bivši sudac Gyaun i njegov sin Pavao. Među Latinima je i bivši sudac Cion, a latinski prisežnik je Ivan za kojeg s velikom vjerojatnošću možemo posumnjati da je identičan Ivanu, sinu Luke Boniolia, kome je Cion bio šogor. Dakle, u četiri slučaja vidimo po dva zastupnika iz jedne obitelji. Međutim, s obzirom na to da su obitelji Gyuana i Šafar rodbinski povezane, to znači da su najmanje četiri građanina u bližoj ili daljnjoj rodbinskoj vezi. Spomenuti građani u magistratu su i sljedeće godine (1414.), osim Ivana Boniolija i Stjepana Šafara. ${ }^{103}$ Sada su funkcije malo izmijenjene: Cion je sudac, a Gašpar je prisežnik, dok su ostali na funkciji vijećnika. U sljedećem sačuvanom sastavu magistrata (1416.) u odnosu na potonji samo nema Gašpara Miklinovog, ali se pojavljuje Andrija, sin Petra Šafara, što znači da obitelj

101 S obzirom na to da nema podataka o sucima za pojedine godine, bolje je upotrijebiti općeniti broj.

102 Tako je u zadnji čas iz gore spomenutih obitelji ispao Nikola Cvetko, sin Demetrija iz Zlata. Naime, u približno isto vrijeme postoji i Nikola Čeko (Chehko), koji se 1446. spominje kao succesor condam relicte Prawz (MCZ 6, str. 437). Iz navedenog izvora ne može biti izričito jasno radi li se konkretno o udovici Ivana Prauza, suca iz 1417., ili o nekom drugom članu te obitelji. Godine 1448. Nikola Cvetko spominje se sa svojom ženom Uršulom kao novi građanin (MCZ 10, str. 91), što dakle ukazuje da je, unatoč sličnosti u prezimenu, ovdje riječ o dva različita građanina.

103 Među Latinima više nema niti jednog Ivana, dok je među njemačkim građanima neki Stjepan klesar za koga sumnjamo da je identičan sa Stjepanom Šafarom. 
Bruno Škreblin: Uloga obiteljskih veza u formiranju gradske elite zagrebačkog Gradeca Zb. Odsjeka povij. znan. Zavoda povij. druš. znan. Hrvat. akad. znan. umjet., 34 (2016), str. 39-87

Gyuan-Šafar ima tri predstavnika u magistratu. ${ }^{104}$ Sljedeće godine (1417.) Gašpar je ponovno prisežnik, njegov otac je vijećnik, a obitelj Gyuana sada ima tri člana u magistratu: pored Gyuana Benediktovog u magistratu su oba njegova sina, Pavao i Benedikt, ali nema Petra Šafara. Godine 1419. u magistratu je Petar Šafar i sva tri predstavnika obitelji Gyuana, što znači da ponovno imamo četvoricu rodbinski povezanih građana. Sljedeće godine u magistratu su oba sina Gyuana, a ponovno se pojavljuje Andrija Šafar, a ista je situacija i 1422. Tada su njihovi očevi Gyuan i Petar Šafar pokojni. Sljedeći sastavi magistrata počinju tek s 1431. ali su, uz manje iznimke sačuvani su do kraja srednjovjekovnog perioda. U tridesetim godinama 14. st. u nekoliko navrata u magistratu se nalaze Jakša i Pero Šafar te Benedikt, sin Gyuana, koji su, kako smo vidjeli rodbinski povezani. Također su često u magistratu Toma, sin Ciona, i njegov ujak Marin Klarić; 1438. Marin je sudac, a njegov nećak je prisežnik.

Uvodno je već ukazano da je nakon 1437. u mnogim slučajevima teže identificirati građane u magistratu jer se oni mnogo češće sada upisuju samo po imenu, a ne navodi se više jezik pojedinog građanina. Naravno i dalje se pojavljuju slučajevi rodbinskih povezanih građana u magistratu: Godine 1445. sudac je Valentin Šaronić, a u magistratu je Marko Sebastijanov, brat Valentinove žene. Dvije godine kasnije prisežnik je neki Juraj, a među vijećnicima se nalazi Marcus filius predicti Georgi jurati. Iste su godine u magistratu i Marko i Benedikt, sinovi Mihaela Sebastijana. ${ }^{105}$

Dakle, u magistratu je moglo biti građana koji su međusobno rodbinski povezani, a najviše je utvrđeno četvoro rodbinskih povezanih građana u istom sazivu magistrata. Zanimljivo da prema njemačkom gradskom pravu, čiji utjecaj je na Gradecu bio velik, u gradskoj se upravi istovremeno najviše moglo nalaziti četiri građana koji su bili u rodu, a to je uključivalo čak i daljnje rođake. ${ }^{106}$ Ipak, bez obzira na tu znakovitu podudarnost, zaključak da na Gradecu također nije moglo biti više od četiri međusobno povezanih građana bio bi ipak ishitren. Naime, iz gore navedenih primjera vidljivo je da rekonstrukcija rodbinskih odnosa najčešće uspijeva kad je riječ o obiteljskim ili bližim rodbinskim odnosima. Svakako da je još moralo biti daljnjih rođaka, i po ženskoj i po muškoj liniji, o čemu izvori uglavnom šute. Tako primjerice saznajemo da su rođaci (cognatus) bili Dominik krznar i Stephanus Kneht, obojica članovi magistrata, $i$ to samo zato jer su se obojica spominjala u nekom sporu. ${ }^{107}$ Pravila o restrikciji članova iste obitelji također $u$ načelu nisu dozvoljavala da se $u$ gradskoj upravi istovremeno nalaze i braća, osim u slučaju da nema drugog časnog građanina koji bi ga zamijenio. ${ }^{108} \mathrm{Na}$ Gradecu ipak postoje slučajevi da se i dvojica braće, ili otac i sin nalaze istovremeno u magistratu. Zbog toga, može se prihvatiti zaključak $S$. Gustafsson da se spomenuti restriktivni propisi ipak nisu mogli provoditi u praksi.

${ }^{104}$ U njemačkoj se skupini nalazi građanin upisan samo kao Enderko, pa s većom sigurnošću pretpostavljamo da je riječ o najstarijem sinu Petra Šafara.

105 MCZ 6, str. 446

106 Sofia Gustafsson, Succession in Medieval Swedish Town Councils, u: Generations in Towns, str. 198.

107 MCZ 6, str. 101

108 Gustafsson, Succession, str. 198. 
Bruno Škreblin: Uloga obiteljskih veza u formiranju gradske elite zagrebačkog Gradeca

Zb. Odsjeka povij. znan. Zavoda povij. druš. znan. Hrvat. akad. znan. umjet., 34 (2016), str. 39-87

Da je u magistratu zasigurno bilo još članova istih obitelji, ili daljnjih ili bližih rođaka, može se pretpostaviti i zbog još jedne važne činjenice. Gradec je u europskih okvirima ipak bio mali grad. Broj punopravnih građana koji su uopće mogli biti biran na dužnosti vjerojatno se kretao oko nekoliko stotina, možda i manje u drugoj polovini 15. st., kada dolazi do tzv. "krize" gradova. S obzirom na to da su se brakovi u srednjoeuropskim gradovima uglavnom sklapali u istom statusnom krugu, o čemu će biti više riječi u sljedećim poglavljima, pretpostavka je da je među samim punopravnim građanima bilo mnogo međusobnih obiteljskih i rodbinskih veza. To je također jedan od razloga zbog čega je restrikcija članova iste obitelji u magistratu mogla biti neprovediva u praksi.

Mogućnost postojanja "nevidljivih" rođaka možemo sagledati primjerom iz obitelji Mihaela, sina Sebastijana. Mihael je svoju političku karijeru započeo devedesetih godina 14. st., kada se spominje kao prisežnik. Njegov otac sudac Sebastijan nije mu u tome mogao pomoći jer je već bio pokojan, ali Mihealu je zasigurno pomogao njegov očuh, sudac iz mađarske skupine Ivan, sin Pavla. Međutim, ostaju nam nepoznati Mihaelovi rođaci po očevoj ali i majčinoj strani. Mihaelova majka Margareta imala je brata Marka Galicusa, što ukazuje da je Margareta porijeklom bila iz obitelji latinskih odnosno talijanskih doseljenika. Bedenko smatra kako je Marko Gallicus zapravo identičan s Markom, sinom Mikeča Leonardovog, koji je gradski sudac 1396. ${ }^{109}$ Mihaelova žena Klara bila je kći Antuna, sina Vide, komu je pak očuh bio Gerin de Spinal, a Mihaelova kći udala se za Valentina Šaronića. Uz to, Mihael, sin Sebastijana, bio je i rođak (consanguineo) Petra Pentere koji je pak u rodbinskoj vezi s članovima obitelji de Medzo i sucem Ivanom Zigeštakom. ${ }^{110} \mathrm{~S}$ obzirom na to da je Petar Pentera imao još troje braće, kao i da je obitelj Šaronić također brojna, vidimo koliko su Mihael Sebastijanov i njegovi nasljednici još imali utjecajnih rođaka.

Mihael Šaronić je prisežnik 1472., kada je sudac njegov otac Valentin. Još je iste godine u magistratu Marko Šaronić, Mihaelov polubrat, odnosno Valentinov sin iz drugog braka. Valentinovi ujaci Benedikt i Marko, sinovi Miheala Sebastijana, tada su pokojni, ali tu je Markov sin Emerik literat te muževi Šaronićevih tetki, zlatari Pavao, Benedikt i Toma Hrvat. Još se valja podsjetiti da je Mihael, sin Valentina, imao trojicu polubraće i dvije polusestre, dok je njegov brat Ladislav vjerojatno do sedamdesetih godina 15. st. sigurno bio pokojan. $\mathrm{O}$ aktivnostima njegove polubraće nema izravnih podataka, ali oni su sigurno bili građani, čime su mogli poduprijeti Miheala Šaronića u njegovoj karijeri. Kada k tome još pridodamo članove obitelji Sebastijana, obitelji žena Mihealove polubraće i druge žene njegovog oca, te muževe njegovih polusestri, dobivamo već dvoznamenkasti broj Mihaelovih daljnjih rođaka odnosno građana koji su mogli stajati iza političke karijere Miheala Šaronića. S druge strane Mihael je, kao uostalom i njegov otac Valentin, također mogao biti od pomoći

109 Bedenko, Društvo i prostor, str. 38.

${ }_{110}$ MCZ 9, str. 262. 
Bruno Škreblin: Uloga obiteljskih veza u formiranju gradske elite zagrebačkog Gradeca

Zb. Odsjeka povij. znan. Zavoda povij. druš. znan. Hrvat. akad. znan. umjet., 34 (2016), str. 39-87

u njihovim aktivnostima, odnosno suci Emerik, sin Marka Sebastijana, kao i zlatar Pavao, lako su mogli računati na podršku Mihaela Šaronića i njegove obitelji. ${ }^{111}$

Zaključno, vrlo je teško utvrditi točan broj članova pojedine obitelji u nekom konkretnom sazivu magistrata jer se daljnje rodbinske veze rijetko navode $u$ izvoru. Međutim, u uvjetima male sredine formalno vršenje neke funkcije članova iste obitelji u pojedinačnom sazivu magistrata ne treba biti jedini kriterij po kojem bismo trebali izvoditi zaključke. Dovoljno je utvrditi rodbinski povezane građane koji obnašaju neku funkciju u otprilike isto vrijeme, primjerice $u$ istom desetljeću. Uostalom, funkcija gradskog suca ima u neku ruku doživotan karakter jer bivši suci čine drugostupanjsko pravno tijelo. Bivši suci ne moraju ponovno formalno obnašati tu funkciju niti se nalaziti u magistratu da bi njihov ugled i utjecaj bio velik u jednoj manjoj sredini u kojoj se građani i članovi magistrata sigurno bolje poznaju i češće susreću negoli je to slučaj u velikim europskim gradovima.

\section{Neke karakteristike srednjovjekovne gradske obitelji}

Obitelj je kao temeljna društvena grupa bila od velike važnosti u srednjovjekovnom gradu kod svih društvenih struktura, pa tako i gradske elite. Moglo bi se zapravo u neku ruku tvrditi da je obitelj čak bila i važnija kod pripadnika gradske elite u prvom redu zbog toga što je pripadnost nekoj uglednoj obitelji bio jedan od najvažnijih društvenih preduvjeta za obnašanje visokih gradskih funkcija. Također se podrazumijevalo da pripadnici gradske elite budu oženjeni, odnosno da imaju vlastitu obitelj..$^{12}$ To je naročito vrijedilo za novopridošle građane čija je ženidba građankom zapravo jamčila njihovu integraciju u društvo. Slikovitu potvrdu o tome, iako ne iz srednjega vijeka, nalazimo u gradskim zapisnicima iz 1699.: Građani, ceh-meštri, obrtnici, i zastupnici općine koji dosad možda nisu oženjeni, zbog časti i staleža i čuvanja dobrog glasa imaju se oženiti u roku od pola godine pod prijetnjom gubitka službe, sramote i globe od 25 ugarskih forinta. ${ }^{113}$ Nešto ranije, 1635., grad donosi propis da: Bogatiji mladići, koji žive s nezakonitim ženama, imaju iste oženiti do sljedeće Pepelnice pod prijetnjom globe od 100 zlatnika. Siromašniji pak morat će podnijeti kaznu koju odredi gradski magistrat. Onima koji se ne bi pokorili ovoj odredbi, bit će zatvorene radionice i trgovine i bit će im zabranjeno da se u našoj sredini bave trgovačkim poslovima sve dok se sasvim ne pokore ovom na$\log u .{ }^{114}$ Premda ove gradske odluke potječu iz ranomodernog doba, slična su očeki-

${ }_{111}$ Naravno, ovdje je, ilustracije radi, pružena idealna slika neke obitelji u kojoj vladaju idilični obiteljski i rodbinski odnosi. U srednjovjekovnoj svakodnevnici moglo je doći do zavade između članova iste obitelji ili rođaka, najčešće oko vlasništva odnosno nasljedstva posjeda. Tako se Dominik, sin Ivana Perovića, prvo sporio sa svojim ocem jer mu nije htio vratiti veću svotu novaca (250 florena). Kasnije se Dominik gotovo redovito sporio oko nasljedstva ili povrata imovine sa svojim sestrama, njihovim muževima, te ženama od svoje braće (MCZ 7, str. 463).

${ }_{112}$ Naravno, to vjerojatno nije vrijedilo ukoliko je građanin u magistratu poznat i ugledan, a ostao je udovac. Primjerice, moguće je da je Cion na sudačkoj funkciji 1422. bio možda udovac i gradski sudac jer je bio dugogodišnji i poznati građanin.

113 Lelja Dobronić, Slobodni i kraljevski grad Zagreb, Zagreb 1992., str. 110.

${ }^{114}$ Isto, str. 97. 
Bruno Škreblin: Uloga obiteljskih veza u formiranju gradske elite zagrebačkog Gradeca Zb. Odsjeka povij. znan. Zavoda povij. druš. znan. Hrvat. akad. znan. umjet., 34 (2016), str. 39-87

vanja i propisi vladali i na srednjovjekovnom Gradecu. Prema odredbi ceha krznara navedenoj u Iločkom statutu novi je član morao zajedno s poštenim ljudima dati jamstvo da će se unutar jedne godine zakonito oženiti i postati otac obitelji. ${ }^{115}$

Važnost obitelji vidi se i kod znamenitih slučajeva pomilovanja osuđenika u kojima je razlog bilo sklapanje braka. Tako je 1462. zvonar Pavao, koji je bio osuđen zbog sudjelovanja u krađi, pomilovan nakon što je jedna djevojka izjavila da će poći za njega kao zakonita žena. ${ }^{116}$ Godine 1499. djevojka osuđena zbog dvostrukog čedomorstva na utapanje u Savi pomilovana je na molbu krvnika, koji ju je uzeo za ženu. ${ }^{117} \mathrm{~S}$ druge strane, gradski stražar Mihael, kriv za bijeg zatvorenika, prognan je iz grada zajedno sa ženom jer ih se propter matrimonium separari nullo modo potuit. ${ }^{118}$

Važnost obitelji u kontekstu istraživanja gradske elite leži u činjenici da su se rodbinske veze najčešće sklapale unutar istog statusnog kruga, što se moglo vidjeti iz gore spomenutih primjera ženidbenih povezivanja gradske elite. Primjerice, s obzirom na to da je Petar Šafar bio sitni plemić, nije isključeno niti da je njegova druga žena Katarina, udovica Žigmunda jurata, bila također plemićkog porijekla: njezina sestra Elizabeta bila je udana za Jurja Maretića, plemića iz Klokoča, a Katarina se nakon Petrove smrti isto tako preudaje za drugog klokočkog plemića Matiju Farkaša. Agnes, sestra Matije notara, sina mesara Luke, udana je za prisežnika Lovru Mađara. ${ }^{119}$ Zetovi Blaža štacunara koji su ranije spomenuti isto su tako štacunari ili kramari, ali i gradski prisežnici. Sklapanje braka unutar statusnog kruga vidljivo je i kod slučajeva preudavanja nakon smrti bračnog partnera, kada udovice obrtnika ili trgovaca preudavaju se za građane istog statusa ili istih profesija. ${ }^{120}$ Udovica prisežnika Gašpara literata ponovno se udala za Matiju krojača, ali također gradskog prisežnika. ${ }^{121}$ Agica, udovica jurata Gašpara, sina suca Miklina, preudala se za jurata Matiju, sina Stjepanovog. ${ }^{122}$ Trgovac Pavao, sin Benedikta iz Vaške, oženio se Dorotejom, udovicom prisežnika Nikole, a potom se i Pavao pojavljuje u magistratu. ${ }^{123}$ Jelena, kći štacunara Ivana, prvi put bila udana za kramara Demetrija, a drugi put za kramara i suca Ivana Bolšaka. Lucija, kći krojača Pavla, bila je prvo žena krojača Blaža, a potom krojača Emerika, Jelena, udovica Ivana trgovca (institor) žena je Ilije trgovca. ${ }^{124}$ Barbara Vrečarić bila je udovica postolara Ivana iz Gorice, a potom žena nekog Nikole postolara. ${ }^{125}$ Margareta, udovica Egidija mačara (purgator gladiorum), udala se ponovno za Petra mačara. ${ }^{126}$ Derek Keen je tako slikovito zaključio da su se u sred-

${ }_{115}$ Karbić, Obitelj, str. 35.

${ }_{116}$ MCZ 7, str. 224-225.

117 MCZ 8, str. 127-128.

${ }_{118}$ MCZ 7, str. 45-46.

${ }_{119}$ MCZ 6, str. 209.

${ }_{120}$ Carpenter, The Formation, str. 144-145.

${ }^{121}$ MCZ 6, str. 196.

${ }^{122}$ MCZ 6, str. 220.

${ }_{123}$ MCZ 7, str. 104, 110

124 Bedenko, Zagrebački Gradec, str. 39-66; MCZ 6, str. 191.

${ }_{125}$ MCZ 7, str. 79.

${ }_{126}$ MCZ 7, str. 94. 
Bruno Škreblin: Uloga obiteljskih veza u formiranju gradske elite zagrebačkog Gradeca Zb. Odsjeka povij. znan. Zavoda povij. druš. znan. Hrvat. akad. znan. umjet., 34 (2016), str. 39-87

njovjekovnim gradovima udovice krojača najradije ponovno se udale za krojače. ${ }^{127}$ Može se pretpostaviti da je obostrani interes pogodovao sklapanju takvog braka: udovice su često bile prisiljene nastaviti posao svog prvog muža, a to je svakako bilo lakše s novim mužem koji se također razumije u posao. $S$ druge strane, njezin novi suprug dobivao je i mušterije njezinog prvog muža ili poslovne kontakte. Svakako da su veliku ulogu u takvom povezivanju imale strukovne bratovštine odnosno cehovi. Tako 18. članak usvojenog križevačkog statuta za gradečki ceh ostrugara, bravara, kovača i cestara glasi: Umre li oženjen majstor, ostali će majstori udovici poslati vještog kalfu koji će joj, dokle bude udovica, upravljati zanatom, ali se za to vrijeme oboje moraju ćudoredno vladati. Ukoliko se udovica preuda za majstora drugog zanata neka se taj kalfa odstrani. ${ }^{128} \mathrm{U}$ drugom članku stoji: Oženi li kalfa udovicu majstora ili majstorov sin kao izučeni kalfa uzme za ženu majstorovu kćer, ... oni plaćaju floren i pol u cehovsku blagajnu. ${ }^{129}$ To je bila upola manja taksa jer je inače novi majstor plaćao tri florena. Dakle, i cehovi su stimulirali ženidbeno povezivanje unutar profesija. Međutim, prema M. Karbić, u takvim situacijama ne treba u potpunosti isključiti mogućnost sklapanja braka iz osjećaja jer su se pripadnici iste profesionalne ili društvene grupe češće družili. ${ }^{130}$ Etnička pripadnost nije pri sklapanju braka igrala ulogu, iako se na primjeru gradečkih Talijana vidi da su se oni vrlo često ženili između sebe, ipak moguće je da se i u tom slučaju radi o ženidbenim vezama unutar profesija pošto su se gradečki Talijani najčešće bavili trgovinom. ${ }^{131}$ Naravno, nije uvijek bilo moguće ostvariti brak u istom profesionalnom krugu. Tako je neka Klara bila udovica Jurja postolara, a ponovno se udala za Ivana lukara (arcupar), ${ }^{132}$ a Jelena, udovica Tome postolara, udala se ponovno za Jurja kupalištara (balneator). ${ }^{133}$ Elizabeta, udovica Valentina štacunara, udala se drugi put za Johannesa klesara (lapicida). ${ }^{134}$

U svakodnevnom životu vjerojatno nije uvijek bilo moguće sklopiti brak koji bi u potpunosti bio odraz statusa supružnika. Tako je Magdalena, kći Gašpara jurata, unuka suca Miklina, prvo bila udovica Ivana mesara zvanog Jansek, da bi se nakon njegove smrti preudala za Klementa tesara. ${ }^{135}$ Kako je ukazao Bedenko, tesari su bili rijetkost u gradskom magistratu zbog toga što je ta obrtnička struka bila među najmanje lukrativnima. ${ }^{136}$ Osim toga, spomenuti je Klement bio i jobagion (zavisni

\footnotetext{
127 Derek Keen, Tanners widows 1300-1350, u: Medieval London Widows 1300-1500, ur. Caroline M. Barron - Anne F. Sutton, London 1994., str. 1-27.

128 MCZ 3, str. XXXIII.

129 MCZ 3, str. XXXI.

${ }^{130}$ Karbić, Obitelj, str. 36.

131 Bedenko, Društvo i prostor, str. 38.

132 MCZ 6, str. 226

133 MCZ 6, str. 177.

134 MCZ 9, str. 324. Za pripadnost muževa i žena različitim profesijama vidi: Marija Karbić, Nije, naime njezina duša drugačija nego kod muškarca. Položaj žene u gradskim naseljima međuriječja Save i Drave u razvijenom i kasnom srednjem vijeku, u: Žene u Hrvatskoj. Ženska i kulturna povijest, ur. Andrea Feldman, Zagreb 2004., str. 63-64.

135 MCZ 7, str. 43-44.

136 Bedenko, Zagrebački Gradec, str. 69.
} 
Bruno Škreblin: Uloga obiteljskih veza u formiranju gradske elite zagrebačkog Gradeca Zb. Odsjeka povij. znan. Zavoda povij. druš. znan. Hrvat. akad. znan. umjet., 34 (2016), str. 39-87

seljak) plemića Ladislava Pezera, pa možemo zaključiti da se Magdalena nije udala unutar svog statusnog kruga. Ne može se isključiti mogućnost da je Magdalena zbog osiromašenja već ranije izgubila status "poželjne" udovice, pa je njezin brak s Klementom zapravo u tom trenutku bio odraz Magdaleninog realnog statusa.

Ponovne udaje ili ženidbe zbog smrti jednog od bračnog partnera na Gradecu bile su vrlo česte, ne samo kod pripadnika gradske elite. Od sudaca najmanje dva puta ženili su se Luka Bonioli, Cion, Petar Šafar, Antun, sin Tome, Mihael Oprašnić, Mihael, sin Sebastijana, a Valentin Šaronić tri puta. S druge strane, Elena, kći Pavla Vugrina, udavala se najmanje četiri puta, Katarina, udovica Žigmunda, Katarina Soldinar i Margareta Ribarica najmanje tri puta. Neke od primjera ponovnih ženidbi već smo ranije spomenuli, ali moglo bi ih se navesti još mnogo. Moglo bi se prije zaključiti da su ponovne ženidbe gotovo bile pravilo, i da je rijetkost bilo da mlađi bračni par zajedno dočeka starost. ${ }^{137}$ Ponovna ženidba nakon smrti bračnog partnera u obiteljima trgovaca ili obrtnika bila je poslovna i životna nužnost jer su udovci smrću svog supružnika pretrpjeli fizički, ekonomski i društveni gubitak. ${ }^{138}$ Supružnici u srednjovjekovnom gradu nisu samo živjeli zajedno i podizali djecu, nego su najčešće i radili zajedno. Zbog toga su se udovci ponovno ženili relativno brzo nakon smrti prve žene. Ingendahl smatra da je udovicama brza ponovna ženidba vjerojatno teže polazila za rukom i neke od njih ipak su morali posao nastaviti same ili uz pomoć djece i rođaka. ${ }^{139}$ Moguće da je razlog tome što su žene ipak češće nadživjele svoje muževe nego obratno, pa je mnogo više bilo udovica. Na Gradecu je u jednom trenutku (prilikom sastavljanja popisa kućevlasnika i stanara 1368.) među tristotinjak vlasnika kuća bilo 33 žene od kojih su više od pola (23) bile udovice. ${ }^{140}$ Međutim, bogate udovice uglednih građana sasvim sigurno nisu imale problema ponovno stupiti u brak, poput Franciske Donati, njezine snahe Katarine, te Katarine, udovice Soldinara. Prvi muž Katarine, spomenute snahe Franciske, bio je prisežnik Žigmund, sin Marka, koji umire sredinom 1416., a kao žena Petra Šafara Katarina se spominje 1419., ali iste godine ponovno ostaje udovica. ${ }^{141}$ Katarinin drugi brak s Petrom bio je moguć u prvom redu zato što je i Šafar u istom vremenu bio udovac. Svakako da su se i drugoj ženidbi pripadnici gradske elite težili ponovno oženiti unutar istog statusnog kruga, što se iz dosad spomenutih primjera moglo vidjeti. Prema C. Carpenter, $\mathrm{u}$ engleskim srednjovjekovnim gradovima postojao je i društveni pritisak na udovice u smislu da se pazilo da ugledne udovice ponovno uzimaju za muževe građane istog statusa. ${ }^{142}$ Treći muž Katarine bio je Matija Farkaš iz Klokoča, pripadnik klokočkog sitnog plemstva, kasnije i gradski prisežnik, a njihov je brak prvi put

\footnotetext{
137 David Nicholas, The Later Medieval City, 1300-1500, London - New York 1997., str. 263.

${ }^{138}$ Gesa Ingendahl, Widows as Successors in Workshop Office and House: A Study of Early Modern Ravensburg, u: Generations in Towns, str. 80.

139 Ingendahl, Widows, str. 80-81.

${ }_{140}$ MCZ 11, str. 227-236.

${ }_{141}$ MCZ 6, str. 35, 68, 77.

${ }^{142}$ Carpenter, The Formation, str. 145.
} 
Bruno Škreblin: Uloga obiteljskih veza u formiranju gradske elite zagrebačkog Gradeca

Zb. Odsjeka povij. znan. Zavoda povij. druš. znan. Hrvat. akad. znan. umjet., 34 (2016), str. 39-87

zabilježen 1423. godine. ${ }^{143} \mathrm{Na}$ Gradecu je pak bio čest slučaj da su se bogatim udovicama ženili gradski došljaci koji su vrlo brzo stekli i društveni ugled. Tako je, ponovimo, Blaž Stojimilić bio oženjen za udovicu prisežnika Augustina Kusne, Andrija Latin oženjen je za Skolastiku, udovicu prisežnika Jurja, sina Benediktovog, brata suca Brikcija, očuha Ivana Perovića. ${ }^{144}$ Jakov Eberspeck oženio se Margaretom, udovicom Brikcija ribara, a Antun Roth se na Gradecu oženio Katarinom Soldinar, udovicom prisežnika Sebastijana Soldinara iz Rovišća, a Blaž, sin Lazarina iz Iloka, Katarinom udovicom Matije, odnosno kćerkom suca Blaža štacunara.

U ovim slučajevima postavlja se pitanje jesi li ti njihovi novi muževi bili već dovoljno ugledni i prije ženidbe ili su tek nakon ženidbe ugledne građanke stekli ugled? Isto pitanje vrijedi i kad su u pitanju zetovi uglednih građana. Primjer Jakova Eberspecka vjerojatno potvrđuje već postavljenu tezu da se brak sklapao unutar statusnog kruga. Jakov Eberspeck, porijeklom iz Konstance, prvo se spominje u gradu kao magister conquine grofova Celjskih. ${ }^{145} \mathrm{~S}$ obzirom na njegovu raniju funkciju i na plemićki status Jakovljeve sestre, može zaključiti da je Eberspeck bio plemić, premda to u gradskim dokumentima nije izričito naglašeno. U svakom slučaju, dolazak Jakova Eberspecka u uskoj je vezi s grofovima Celjskim i njihovom vrhovnom vlašću na Gradecom. Dakle, taj slučaj potvrđuje sklapanje braka unutar približno istog statusnog kruga pa možemo zaključiti da su i spomenuti došljaci bili istog ili makar sličnog statusa kao i te udovice, ali je za njih ženidba nekom udovicom (ili kćerkom uglednog građanina) predstavljala dobru priliku i za integraciju i punu afirmaciju unutar gradske elite.

Pri sklapanju prvog braka, ukoliko su roditelji bili živi, njihov utjecaj na odabir bračnog druga mogao je biti presudan. Očevi su često dugotrajno prijateljstvo s drugim građaninom ili poslovno partnerstvo nastojali zaokružiti brakom između svoje djece ako se ukazala takva prilika. ${ }^{146}$ Tako bismo mogli pretpostaviti da su Mihael, sin Šimuna (Šaronić), i Mihael, sin Sebastijana, dogovorili ili vrlo blagonaklono gledali na brak između svoje djece Valentina i Jelene. U svakom slučaju, taj brak odaje blisku povezanost tih dvaju gradskih sudaca iz slavenskog jezika. Isto tako, i Petar Šafar i njegova druga žena Katarina sigurno su utjecali da njihova djeca Jakov, sin Petra, i Margareta, kći Katarine i njenog prvog muža, sklope brak, iako bi naravno ovdje mogli primijeniti mišljenje kako se moglo raditi o braku iz osjećaja jer su zahvaljujući braku njihovih roditelja Jakov i Margareta bili često u doticaju. Žendiba Cionove kćerke plemićem iz Brežica također je mogući rezultat njihovog rani-

\footnotetext{
${ }^{143}$ MCZ 6, str. 118.

${ }_{144}$ Za Blaža Stojimilića, vidi: MCZ 10, str. 221. Za Andriju Latina, vidi: MCZ 10, str. 9.

${ }^{145} \mathrm{MCZ} 10$, str. 38. U tom dokumentu Eberspeck je upisan kao Jakov, sin Ulrika, ali se spominje njegova sestra Katarina te njezin muž Johannes occulista. U ranijem se dokumentu (1437.) spominje Katarina i njezin muž Johannes occulista Panczerer iz Constance, dakle istog grada iz kojeg je bio i Jakov (MCZ 9, str. 299-300). Svaku sumnju otklanja treći dokument (1445.) u kojem se spominje Katarina, kći Ulrika Eberspecka, udovica magistra Johannesa iz Constance (MHEZ 7, str. 46-47). U njemu je naznačeno da je Katarina plemićkog statusa.

${ }_{146}$ Carpenter, The Formation, str. 139-140.
} 
Bruno Škreblin: Uloga obiteljskih veza u formiranju gradske elite zagrebačkog Gradeca

Zb. Odsjeka povij. znan. Zavoda povij. druš. znan. Hrvat. akad. znan. umjet., 34 (2016), str. 39-87

jeg poznanstva nastalog Cionovim trgovačkim aktivnostima, pošto su građani često trgovali na prostoru Kranjske, a Brežice su bila prva postaja na tom trgovačkom putu.

\section{Nasljeđivanje imovine}

Razlozi čestog pojavljivanja sinova bivših sudaca ili prisežnika na funkcijama gradskog magistrata ne leže samo u nasljeđivanju ugleda i statusa svojih očeva, nego i u nasljeđivanju njihovih materijalnih dobara. Zbog toga je potrebno obratiti pozornost i na neke osnovne principe nasljeđivanja imovine. Ipak, valja ukazati da je nasljeđivanje imovine u srednjem vijeku previše kompleksna tema da bi se ovdje o tome pružio valjani osvrt zbog čega će se ovdje govoriti tek osnovnim crtama uz ilustraciju s nekoliko primjera iz Gradeca.

Jedna od glavnih karakteristika srednjovjekovnog Gradeca, kao i drugih kontinentalnih gradova u Europi, jest izjednačenost ženskih i muških nasljednika. Prema tavernikalnom pravu, koje je vrijedilo i na Gradecu, oba spola bila su izjednačena u nasljednom pravu, a žena je bila nasljednik prvog reda zajedno s djecom, ako je došlo do smrti supruga-ostavitelja, a prilikom raspodjele imovine roditelja kćerke su imale jednak pravni tretman kao i muški nasljednici. ${ }^{147} \mathrm{U}$ takvim se okolnostima nije moglo razviti načelo primogeniture i najstariji sin nije mogao računati na bilo kakvu prednost u raspodjeli nasljedstva, niti su općenito sinovi mogli računati na prednost pred svojim sestrama.

Osim jednakog udjela u raspodjeli obiteljske imovine, prilikom sklapanja braka žena je dobivala darove od oca majke ili treće osobe (res paraphernales) s kojima je uvijek imala pravo slobodno raspolagati čak i u slučaju smrti bračnog partnera i preudaje. ${ }^{148}$ Također, muž je svojoj ženi prilikom sklapanja braka obično davao novčanu svotu ili zemljišni posjed, a taj se običaj pravno nazivao dos. ${ }^{149}$ Institut miraza na srednjovjekovnom Gradecu nije zabilježen, ali je postojala praksa da žena mužu daruje svoje nekretnine. Takvih je primjera mnogo, zbog čega ističemo samo one koji spominju pripadnike gradske elite: Katarina, udovica Petra Šafara, poklanja dio svoje palače trećem mužu Matiji Farkašu; Doroteja, kći krojača Blaža, poklonila je svoju drvenu kuću i dućan kramaru i prisežniku Tomi Chedenu, sinu Jakova; Lucija, udovica suca Ivana Zigeštaka, dio palače de Medzo poklanja svom drugom mužu Mihaelu iz Božjakovine; Doroteja, kćerka Tome, zeta Blaža štacunara, svoj dio palače poklanja mužu Jurju Vitkoviću iz Modruša, a Katarina, udovica Soldinara, poklanja sve posjede koje je naslijedila od drugog muža svom trećem mužu Antunu Rothu, iako je iz prethodnog braka imala sina Ivana. ${ }^{150}$ Iako nemamo za to direktnih poda-

${ }_{147}$ Karbić, Obitelj, str. 55; Apostolova-Maršavelski, Iz pravne prošlosti, str. 53.

${ }^{148}$ Više o tome vidi: Karbić, Women and Property, str. 444-446.

${ }^{149}$ Karbić, Obitelj, str. 47. U praksi se može vidjeti da je dos bio isplaćivan i sa ženine strane: tako je sudac Ivan Bolsak dao u ime naknade za dos i res paraphernales Klari, kćeri Luke iz Steničnjaka, udovici svoga sina Ivana i ženi Dominika, sina suca Ivana Perovića, kupalište sa zemljištem. Vidi. MCZ 11, str. 16.

150 Bedenko, Zagrebački Gradec, str. 51. 
Bruno Škreblin: Uloga obiteljskih veza u formiranju gradske elite zagrebačkog Gradeca

Zb. Odsjeka povij. znan. Zavoda povij. druš. znan. Hrvat. akad. znan. umjet., 34 (2016), str. 39-87

taka u izvorima, vrlo vjerojatno na isti način do vlasništva nad svojim velikim kućama ili palačama došli i Mihael, sin Sebastijana, i Cion, sin Ivana. ${ }^{151}$ Naravno, kao i u slučaju res paraphernales, čest je slučaj da bračne partnere daruju ženini roditelji: Margareta, žena suca Nikole Petrovog, poklanja kuću s zidanim dućanima svom zetu Ivanu Krstitelju i kćeri Barbari, a Margareta, majka Ivana Perovića, poklanja svojoj istoimenoj unuci i njezinom mužu Nikoli, sinu Damjana, jedan dućan na Gradecu. ${ }^{152}$

Prema M. Karbić, ustanova darovanja nekretnina za muža bila je povoljnija nego miraz na koji bi u principu muž imao tek pravo uživanja, iako postoje i slučajevi gdje je žena darovala nekretnine uz uvjet da joj budu vraćene u slučaju smrti supruga. ${ }^{153}$ Primjer jednog osiguranja u slučaju smrti pokazuje slučaj dogovor Katarine Soldinar i Antuna Rotha koji 1456. sklapaju ovakav dogovor: Antun u polog daje 100 florena, a Katarina 200 te ako Antun umre prvi, Katarina dobiva njegov novac, a ako ona umre prva, tada Antun dobiva Katarininih 200 florena uz izričitu napomenu da na taj novac ne mogu polagati pravo njegova braća i rođaci kao niti Katarinina djeca. ${ }^{154}$

U slučaju smrti bračnog partnera znalo je dolaziti do sudskih sporova oko povrata dara, ili res paraphernales. Agneza Pravdić nakon smrti muža Andrije Šafara sudskim je putem uspjela vratiti res paraphernales od Andrijine braće Petra i Jakova, međutim nije uspjela dobiti dio muževih nekretnina jer u njezinom braku s Andrijom nije bilo potomaka. ${ }^{155}$ Dominik Perović također je uspio dobiti povrat nekretnina od udovice svog brata. ${ }^{156}$

Apostolova-Maršavelski smatrala je da se u sporovima oko povrata dara (koji je podsjetimo, najčešće bila nekretnina) u slučajevima bez potomaka u braku, gradski sud nije vodio samo pravnim običajima, nego je uzimao u obzir i imovinsko stanje žene kako ona ne bi zapravo povratom dara bila financijski ugrožena. ${ }^{157} \mathrm{Zbog}$ običaja darivanja svog bračnog partnera, ženi bi se u tom slučaju otežala i ponovna udaja. Osim toga, testamentarna raspolaganja uglavnom su bila u korist udovica, čak ako u braku nije bilo djece. ${ }^{158}$

Ono što je također vidljivo u praksi srednjovjekovnog Gradeca jest i briga obitelji za materijalni položaj svojih ženskih članova, osobito ako su ostale udovice ili su još neudane.

Nasljednici pokojnog Donata dijele između sebe imovinu tako da Ivan, sin Mihaela zvani Vitez, ostavlja Franciski, kćerki Gyuana i unuci spomenutog Donata zasigurno najvrjedniju obiteljsku imovinu: palaču sa dućanima i kapelom koja se prostire na pet kurija. ${ }^{159}$ Franciska taj cijeli posjed poklanja svom drugom suprugu Iva-

\footnotetext{
${ }_{151}$ Bedenko, Društvo i prostor, str. 40-41.

${ }_{152}$ MCZ 10, str. 125; Bedenko, Zagrebački Gradec, str. 52.

${ }^{153}$ Karbić, Obitelj, str. 51.

${ }_{154}$ MCZ 10, str. 167.

${ }_{155}$ MCZ 9, str. 181-182.

${ }_{156}$ MCZ 8, str. 73-75.

157 Apostolova-Maršavelski, Iz pravne prošlosti, str. 143.

158 Isto, str. 145.

159 Bedenko, Zagrebački Gradec, str. 44-45.
} 
Bruno Škreblin: Uloga obiteljskih veza u formiranju gradske elite zagrebačkog Gradeca Zb. Odsjeka povij. znan. Zavoda povij. druš. znan. Hrvat. akad. znan. umjet., 34 (2016), str. 39-87

nu Gračinu. Do spomenutog posjeda nalazila se još jedna gradska palača koju 1444. kupuje sudac Ivan Perović, da bi je poklonio svojoj kćeri Magdaleni, očito prilikom udaje za prisežnika Andriju 1451. godine. ${ }^{160}$ Preko puta bila je smještena još jedna palača suca Blaža štacunara koju nakon njegove smrti nasljeđuju kćerke Agneza i Katarina, iako je Blaž imao još djece: sinove Jurja, Matka, Mihaela te kćer Doroteju. ${ }^{161}$ Kao dobar primjer raspodjele nasljedstva može poslužiti sudbina posjeda Mihaela Sebastijana nakon njegove smrti. Mihaelova najstarija kći Jelena još je prilikom udaje za Valentina Šaronića dobila zemljišne posjede - pet selišta ovisnih seljaka u Podbrežju, a nakon njezine smrti zemlja je oporučno ostavljena njezinim sinovima. ${ }^{162}$ Druga Mihaeleova kći, Katarina, dobiva spomenutu kuću u današnjoj Kamenitoj ulici, vrt u podgrađu, te dva selišta sa seljacima u Podbrežju.$^{163}$ Katarina je umrla bez nasljednika te je spomenute posjede oporučno ostavila svom mužu Leonardu. ${ }^{164}$ Nakon smrti Mihaela Sebastijana 1444. dolazi i do izvršavanja oporuke i podjele njegovih posjeda. U toj podjeli preostalim kćerkama pripali su zemljišni posjedi izvan grada, a najvrjedniji posjed, palača s dućanom nedaleko od Kamenitih vrata pripala je mlađem sinu Marku. Treća kći, Uršula, dobiva tri selišta u Pobrežju i vrt kod Manduševca, ${ }^{165}$ a Barabari je pripalo tri selišta te kupalište blizu samostana Sv. Marije, nedaleko od Krvavog mosta, što je ona 1451. poklonila svom mužu. ${ }^{166}$

Iako se na spomenutim primjerima ne može generalno tvrditi da su žene prolazile bolje u podjeli nasljedstva jer ovdje analiziramo mahom bogate građane koji sigurno imaju još različitih zemljišnih posjeda, kuća, a vjerojatno i gotova novca koji se nikada izravno ne spominje, zanimljivo je da postoje slučajevi u kojima ženski nasljednici dobivaju najvrjednije nekretnine koje one potom najčešće daruju svojim muževima. Sasvim sigurno, takva je praksa usko i vezana uz njihovo stupanje u brak. To je suprotno običaju u dalmatinskim komunama gdje su patriciji mnogo radije davali miraz u novcu ili pokretninama kako bi obiteljski posjedi ostali u patrilinearnom sustavu nasljeđivanja i kako ne bi došlo do njihovog otuđivanja. ${ }^{167}$

Tako možemo vidjeti kako su zetovi i muževi udovica u principu materijalno prosperirali ženidbenim povezivanjem. Naravno, odmah se postavlja pitanje - a što je bilo sa sinovima uglednih građana koji su uostalom isto tako morali biti i zetovi uglednih građana? Nažalost, može se rekonstruirati tek nekoliko ženidbenih veza između sinova gradečke elite. To ne znači da nisu poznata imena supruga nekih članova gradske elite, ali najčešće nije moguće ništa reći o obiteljskom porijeklu njihovih žena. Mihael, sin suca Sebastijana, bio je oženjen Klarom, kćerkom Antuna Vide i udovicom Zaharije jurata, Andrija Šafar bio je oženjen Agatom, kćerkom Klementa

\footnotetext{
160 MCZ 10, str. 123.

161 MCZ 10, str. 170.

162 MCZ 9, str. 319

163 MCZ 9, str. 331

164 MCZ 10, str. 4

165 MCZ 10, str. 47, 139.

166 MCZ 10, str. 127-128.

167 Nikolić, Rođaci i bližnji, str. 65.
} 
Bruno Škreblin: Uloga obiteljskih veza u formiranju gradske elite zagrebačkog Gradeca Zb. Odsjeka povij. znan. Zavoda povij. druš. znan. Hrvat. akad. znan. umjet., 34 (2016), str. 39-87

Pravdića, koja će se poslije preudati za suca Jakova Bola. Nažalost, o Klementu Pravdiću ne možemo puno reći, iako je vjerojatno riječ o boljestojećoj obitelji. Pavao, sin Gyuana bio je oženjen Jelenom, kćerkom Pavla Vugrina, ali isto tako pripadnike njezine obitelji ne možemo identificirati u sastavima magistrata.

Možemo samo pretpostaviti da su i njihove žene ipak bile makar približno istog statusa. Ono što međutim upada u oči jest činjenica da sinovi sudaca unatoč svom ugledu i bogatstvu uglavnom ne uspijevaju postati suci, nego ostaju na dužnosti prisežnika. Sinovi sudaca koji su dosegli "samo" čast prisežnika bili su: Toma, sin Ciona, Benedikt i Marko, sinovi Mihaela Sebastijana, Benedikt i Pavao, sinovi suca Gyuana, Jakšin i Pero, sinovi Šafara, Janko, sin Ivana Bola, Perenchlo, sin suca Jakomela Quirina, Gašpar, sin Miklina, Ivan, sin Luke Boniolia, Mihael, sin Valentina Šaronića, Barnaba, sin Andrije de Zwinaria. Žigmund iz latinske skupine bio je prisežnik jednako kao i njegov otac Filip, sin Marka.

Dakle, vidljivo je kako je bilo mnogo sinova sudaca koji su ostali samo na funkciji jurata, iako su pojedini bili sinovi najbogatijih građana poput Ciona ili Mihaela Sebastijana. Istražujući rodbinske poveznice između sudaca i nekih prijašnjih članova magistrata mnogo češće pojavljuju se građani koji su zetovi bivših sudaca ili pak muževi uglednih udovica. Jedini suci koji su ujedno bili i sinovi sudaca su Mihael, sin suca Sebastijana, Valentin, sin Mihaela Šaronića, Andrija, sin Petra Šafara, Jakov, sin Ivana, i Ivan, sin Jakova Bola, te Dominik, sin Ivana Perovića. Zanimljivo da niti jedan od očeva spomenutih sudaca nije bio više živ kada su njihovi sinovi obnašali sudačku dužnost. Također, možemo spomenuti slučajeve u kojima su suci bili sinovi nekadašnjih jurata, dakle sinovi su bili uspješniji od svojih očeva. To su Stjepan Ortoflić, sin Mihaela, Emerik, sin Marka Sebastijanovog, Ivan, sin Pere iz Firence (Perović), Ivan, sin Sebastijana Soldinara i Mihael Oprašnić, sin Antuna.

S obzirom na veći broj utvrđenih afinatskih veza kod sudačkih obitelji, možemo zaključiti kako su one naročito za sudačku funkciju bile važnije od patrilinearnih. Čak u pojedinim slučajevima gdje je utvrđena patrilinearna poveznica osoba u magistratu poput u obitelji Mihaela Sebastijana, Šaronića, Šafara, Perovića i Oprašnića, kod istih postoje i jake afinatske veze s drugim obiteljima iz gradske elite. Ipak, ne bismo mogli zaključiti kako patrilinearne veze u generalnom smislu nisu značajne u društvenom uspjehu jer ne treba obezvrijediti funkciju prisežnika pošto oni također imaju i ugled i znatne prerogative moći, odnosno i gradski prisežnici su spadali u vrh gradske elite. Ipak, biološki razlozi mogli su utjecati na krhkost patrilineranih veza kao i na dugotrajnost pojedinih obitelji u političkom smislu, što zahtijeva zaseban osvrt u sljedećem potpoglavlju.

\section{Struktura obitelji}

Za razliku od dalmatinskih gradskih komuna, u gradovima srednje Europe dominira jednostavan tip obitelji, što znači da je ona sastavljena od supružnika i njihove djece, a djeca se nakon punoljetnosti odvajaju od svojih roditelja te zasnivaju vlastite 
Bruno Škreblin: Uloga obiteljskih veza u formiranju gradske elite zagrebačkog Gradeca

Zb. Odsjeka povij. znan. Zavoda povij. druš. znan. Hrvat. akad. znan. umjet., 34 (2016), str. 39-87

obitelji. Ta punoljetnost prema Budimskom statutu nastupa sa navršenih 14 godina za muškarce a 12 za žene, a po svemu sudeći slično je bilo i na Gradecu. ${ }^{168}$ Također, gradske obitelji imale su malo djece, što je prije svega rezultat visoke stope smrtnosti djece bilo kao novorođenčadi ili do adolescentske dobi. Rezultati istraživanja mađarskih povjesničara za gradove Šopron i Budim daju približno iste rezultate: Szende je analizom požunskih i šopronskih oporuka zaključila da najveći broj oporučitelja ima jedno ili dvoje djece, ${ }^{169}$ a Kubinyi je zaključio da je prosjek djece $u$ srednjovjekovnom Budimu iznosio $1,4 .{ }^{170} \mathrm{U}$ slučaju spominjanja djece $\mathrm{u}$ oporukama za pretpostaviti je da su oporučitelji ranije imali još djece koja u trenutku sastavljanja oporuke više nisu bila živa. Na Gradecu je primjerice Ivan Perović nadživio najmanje dvije kćeri, a Katarina, udovica Petra Šafara, osim što je nadživjela sve svoje muževe, nadživjela je i svoju jedinicu Margaretu, ali i svoju unuku koja je vjerojatno umrla do zrele dobi. Također, prosjek broja djece je, naravno, dobiven od ukupnog broja, što znači da su postojale obitelji i s više djece, ali i one u kojima djece nije bilo. Szende je zaključila da u više od pola slučajeva oporučitelji u trenutku sastavljanja oporuke nisu imali djece, premda je sama autorica bila skeptična da je taj broj realan jer su ljudi bez djece više motivirani za sastavljanje oporuke. ${ }^{171}$ Ipak, i primjer kasnosrednjovjekovnog Londona pokazuje sličnu sumornu sliku glede bioloških nasljednika: polovica srednjovjekovnih londonskih trgovaca nije uopće imala djece, a nešto manje od polovice trgovca koji su imali djece nisu pak imali muškog nasljednika. ${ }^{172}$ Gradečke obitelji Mihaela Sebastijana, Ivana Perovića, Valentina Šaronića, Blaža štacunara i Šafara primjeri su obitelji s puno djece, u smislu da je većina te djece uglavnom dosegla barem zrelu dob. S druge strane, od sudačkih obitelji može se utvrditi da su vjerojatno bez pravih bioloških nasljednika umrli Jakov Eberspeck, Antun Roth, Brikcije, sin Benedikta, Andrija Šafar, Juraj, sin Valentina, ali vjerojatno je taj broj veći jer za mnogo drugih sudaca nema podatka o njihovim biološkim nasljednicima.

Naravno, moguće je da su neki suci imali su ženske nasljednike, pa se rodbinska poveznica nažalost često gubi u izvorima. Od sudaca Andrije Latina i Franje, sina Marka, jedino znamo za kćerke. Franjo, sin Marka, imao je kćer Margaretu udanu za plemićkog suca Nikolu Denešića, dok je jedna kćerka Andrije Latina, Elizabeta, bila udana za prisežnika Sebastijana Ljubaka, a druga, Magdalena, za krojača Demetrija,

168 Karbić, Obitelj, str. 91.

169 Katalin Szende, The Other Half of the Town: Woman in Private, Professional and Public life in Two Towns of Late Medieval Hungary, u: Women and Power in East Central Europe - Medieval and Modern, ur. Mariane Saghy, East Central Europe, sv. 20-23, Budapest 1993.-1996., str. 171-190.

${ }^{170}$ Usp. András Kubinyi, A budai és pesti polgárok családi összeköttetései a Jagelló-korban, Levéltári Közlemények, sv. 37, Budapest 1966., str. 227-291.

171 Szende, The Other Half, str. 177.

172 Vanessa Harding, Sons, Apprentices, and Succesors: The Transmission of Skills and Work Opportunities in Late Medieval and Early Modern London, u: Generations in Towns, str. 154. 
Bruno Škreblin: Uloga obiteljskih veza u formiranju gradske elite zagrebačkog Gradeca Zb. Odsjeka povij. znan. Zavoda povij. druš. znan. Hrvat. akad. znan. umjet., 34 (2016), str. 39-87

sina Pavla. ${ }^{173}$ Od prisežnika Antuna Renisa također se spominje samo kći Margareta, ali nju je nemoguće identificirati kao ženu nekog građanina.

Jednostavna obitelj, uz visoku smrtnost djece, uzima se kao jedan od razloga zbog čega se u srednjoeuropskim gradovima nisu mogle uspostaviti obiteljske dinastije koje vladaju u nekoliko generacija. Rijetkost je da se neka obitelj može pratiti u više od tri generacije. ${ }^{174}$ Neki suci ako i jesu imali djece, često njihovi prvi nasljednici nisu uspjeli osigurati potomstvo. Od mnogobrojne djece Mihaela Sebastijana poznat je samo jedan njegov unuk. Svakako upada u oči da su gradečke obitelji koje su davale suce ili prisežnike u više generacija, poput Sebastijana, Šaronića i Perovića i bile brojnije obitelji s više djece. Dakle, iako se ne čini da je ostvarivanje potomstva bilo problematično kada se uzme u obzir koliko sudaca ipak ima biološke nasljednike, na duži su rok biološki razlozi ipak utjecali na nemogućnost ostvarivanja obiteljskih dinastija.

Zbog toga nije neobično što su građani tražili druge načine za osiguranje potomstva, i pomoći u starosti. Pojedini građani tako su pribjegli sistemu adopcije. Možemo s velikom sigurnošću pretpostaviti da su gradečki obrtnici, ako već sami nisu imali nasljednika, najčešće posinili ili ostavili cijelo ili dobar dio nasljedstva svojim nekadašnjim šegrtima, kako je to bilo i u drugim kontinentalnim gradovima. ${ }^{175} \mathrm{Ta}-$ ko su Friche i njegova žena Katarina u poodmakloj dobi adoptirali trgovca Marka te mu prepisali sve svoje posjede. ${ }^{176}$ Jelena, udovica suca Nikole Fabijanovog, adoptirala je rođaka Nikolu, sina Blaža, tražeći osim doživotne skrbi i da riješi njezine dugove. Nikola je tom adopcijom dobio polovicu njezinog imetka, a na drugu polovicu imao je pravo tek nakon Jelenine smrti. ${ }^{177}$ Zlatar Nikola adoptirao je, u ovom slučaju pobratimio, Antonija zemljoradnika iz Zeline te mu poklonio neke posjede. ${ }^{178} \mathrm{Naj}$ znamenitiji slučaj adopcije zbiva se 1446. kada Benedikt, sin Gyuana, sklapa sporazum o uzdržavanju sa zagrebačkim biskupom Benediktom de Zolio. ${ }^{179}$

Međutim, iako je mnogo djece jamčilo biološki opstanak neke obitelji, s druge strane to je također je značilo da će se roditeljski imetak razdjeljivati na više dijelova. Kao što je navedeno, nepostojanje primogeniture i izjednačenost muških i ženskih nasljednika značilo je jednaku raspodjelu očevog bogatstva sinovima i kćerima. To$\mathrm{ma}$, sin bogatog Ciona, dijelio je nasljedstvo samo s polusestrom Dorotejom, što mu je omogućavalo i više nego pristojan život, ali nakon njegove smrti Tomin se imetak ponovno dijelio između njegovo troje djece. Isto se može reći i za Petra Šafara (ml.) koji je imao četvoro djece, i za djecu Blaža štacunara kojih je bilo šestoro. Ovo su još nasljednici najbogatijih građana koji ipak uspijevaju održati svoj status barem u

${ }_{173}$ Za kćerku suca Franje, vidi: Bedenko, Zagrebački Gradec, str. 57. Za kćerke Andrije Latina, vidi: MCZ 10, str. 4, 123, 236.

${ }_{174}$ Carpenter, The Formation, str. 119.

${ }_{175}$ Barbara Hanawalt, Growing Up in Medieval London: the Experience of Childhood in History, Oxford 1993., str. 171.

176 MCZ 9, str. 130-131.

177 MCZ 10, str. 116-117.

178 MCZ 9, str. 251

179 MCZ 10, str. 77-78. 
Bruno Škreblin: Uloga obiteljskih veza u formiranju gradske elite zagrebačkog Gradeca

Zb. Odsjeka povij. znan. Zavoda povij. druš. znan. Hrvat. akad. znan. umjet., 34 (2016), str. 39-87

dvije generacije. Međutim, podjela imovine na više nasljednika nekog običnog građanina, sitnog trgovca ili obrtnika, dotada uglednog vijećnika ili prisežnika mogla je doista prouzročiti da njegovi sinovi, ako se još nisu dobro oženili, znatno izgube i na svom društvenu statusu.

Iako Gradec vjerojatno nije previše odudarao od drugih srednjovjekovnih gradova po pitanju smrtnosti djece, ne može se zaključiti kako se dominacija patrilinearnih veza na Gradecu nije ostvarila isključivo zbog bioloških razloga. Primjeri postojećih patrilinearnih veza u magistratu koji su iznijeti dovoljni su za takav zaključak. Biološki razlozi svakako su ograničavali obiteljske dinastije, ali nisu bili jedini krivac za nemogućnost održavanja političke moći kroz više generacija. Drugo je pitanje zbog čega mnogi sinovi sudaca, iako ugledni i bogati, nisu naslijedili očeve na istoj funkciji? Ne samo da sinovi sudaca nisu bili privilegirani za "nasljeđivanje" sudačke funkcije, nego bi se prije moglo tvrditi suprotno - da se kod sudačke funkcije javlja svojevrsna "diskriminacija" sinova bivših sudaca, odnosno da je gradska elita na mjestu suca ipak radije vidjela nekog novog građanina. Možemo samo nagađati leži li razlog u želji da se izbjegne drugostupanjski sudski postupak u kojem bi među starijim sucima bili i otac i sin, zbog čega su sinovi sudaca na istu funkciju došli tek nakon smrti njihovih očeva. Ne može se isključiti ni biološki razlog - sudačka funkcija podrazumijevala je stariju dob, pa očevi sudaca uglavnom nisu doživjeli društveni uspjeh svojih sinova.

\section{Dodatni osvrt na dugotrajnost obitelji u političkom smislu}

Brojni primjeri "nasljeđivanja" funkcija pokazuju da su građani težili zadržati politički i društveni utjecaj u više generacija. U političkom smislu najdugotrajnija je bila obitelj Sebastijana, u čak četiri generacije, a obitelji Šaronić, Oprašnić, Perović, Bole, politički je utjecaj zadržala u tri generacije. Još je više primjera obitelji koje su zadržale politički utjecaj u dvije generacije. Ranije smo utvrdili da je gotovo pola sudačkih mandata poteklo iz 15 različitih obitelji. Međutim, govoriti da su Gradecom vladale obiteljske "dinastije" moglo bi navesti na pogrešni put, jer je vladavina mnogih tih obitelji zapravo bila najčešće produljivana afinatskim putem, odnosno primanjem novog člana. Tako se ponovno može postaviti pitanje je li riječ o staroj obitelji ili se može govoriti novoj obitelji koja se gradi na ugledu i moći one starije?

Postoje mnogi slučajevi kada se u izvorima spominju sinovi bivših sudaca ili prisežnika, međutim više ih se ne može identificirati kao članove magistrata te zapravo dolazi do prekida kontinuiteta u političkom smislu. Primjeri nasljednika Tome Cionovog, Petra Šafara mlađeg, Jakova Bola mlađeg zanimljivi su i zbog tzv. "nevidljivosti" pojedinih generacija, odnosno slučajeva kada znamo iz najmanje jednog izvornog podatka da postoje nasljednici nekog građana-pripadnika elite, ali oni se više ne mogu sa sigurnošću identificirati u magistratu, a mnogi od njih ne spominju se više u gradskim izvorima. Može se pretpostaviti da su pripadnici "nevidljive" generacije zbog gubitka materijalne snage izgubili i na društvenom statusu. Djeca 
Bruno Škreblin: Uloga obiteljskih veza u formiranju gradske elite zagrebačkog Gradeca Zb. Odsjeka povij. znan. Zavoda povij. druš. znan. Hrvat. akad. znan. umjet., 34 (2016), str. 39-87

suca Andrije de Zwinaria, Barnabas, Skolastika, Magdalena i Jelena tako su zbog nekih dugova svoga oca bili prisiljeni prodati njegovu kuću. ${ }^{180}$ Osiromašenje je također moglo potaknuti i napuštanje grada, bilo stalno ili privremeno. Doduše, odlazak iz grada ne mora uvijek biti prouzrokovan siromaštvom, nego su neki građani vjerovali da će im druga sredina biti povoljnija za život. Jedna od većih sloboda koje je građanin uživao, sloboda kretanja, omogućavala je osobnu pokretljivost ili jednostavno rečeno, pravo da pojedinac proda sve što ima i ode u drugu sredinu. Tako je gradsko stanovništvo vrlo mobilno i čest je slučaj da druga ili treća generacija jedne obitelji odlazi u druga urbana središta, samo su o tome rijetki podaci u gradskim izvorima. Takve sada izvori spominju u njihovim novim sredinama. Tako primjerice u knjigama srednjovjekovnog riječkog notara iz sredine 15. st. vidimo dvojicu građana Stefana Clibanaria de Zagrabia te Antonija, sina Nikole Krajačića iz zagrebačkog Gradeca. ${ }^{181}$ Već je bilo ukazano da je jedan pripadnik obitelji Šaronić, Juraj, sin Mihaela, otišao u Ilok, a zlatar Nikola Petrov otišao je u Varadin, Leonard Athawantis vratio se $\mathrm{u}$ Firencu, a Marin Klarić u Senj. Za razliku od Athawantisa, preostali gore spomenuti građani ne gube vezu s Gradecom. Marin Klarić, sudac iz 1438., sredinom 15. st. vratio se iz rodnog Senja, gdje je također obnašao funkciju gradskog suca te je na Gradecu vodio brigu o Tominoj djeci i kao njihov staratelj prodaje neke njihove posjede i kuće. ${ }^{182}$ Nikola Petrov napušta grad za vrijeme vladavine Celjskih, ali se vraća nakon njihovog pada, dakle moguće da je njegov odlazak bio političke naravi.

Iako je gotovo pravilo da sinovi sudaca budu politički aktivni, čini se da to ipak nije bio slučaj kod svih. Kao što u gradu mogu postojati i bogatiji građani koji ne ulaze u magistrat, ili se zadovoljavaju najnižom funkcijom vijećnika bez daljnjih ambicija, tako zasigurno postoje sinovi sudaca ili prisežnika koji nisu vidjeli svoju budućnost u političkom angažmanu. Gradečki zlatar i sudac Ivan Božov imao je sina Rafaela koji se spominje bio vitez (miles). Rafael se nekoliko puta javlja u izvorima, po čemu vidimo da je u gradu, ali prema dostupnim podacima nikad nije član magistrata.

Ne treba isključiti mogućnost da su neki nasljednici gradečkih sudačkih obitelji postali svećenici ili su stupili u samostan. Nikola Bole, sin suca Ivana, bio je svećenik i župnik gradečke crkve sv. Marka, a jedna kći Ivana Perovića spominje se kao redovnica u Pečuhu. Jakov Bole, brat spomenutog Nikole Bola, kao klerik dobiva 1401. od pape Bonifacija posjede župe Ivanić. ${ }^{183}$ Neki Mihael, sin Blaža iz Gradeca, 1401. imenovan je od pape za zagrebačkog kanonika, ${ }^{184}$ a istu službu dobiva 1436. Urban, sin Matije iz Gradeca. ${ }^{185}$ Matija, sin Mihaela krojača, bio je župnik u Rakovcu. ${ }^{186}$ Odlazak u svećenike mogla je potaknuti i blizina i utjecaj Kaptola te su neki građani

${ }^{180}$ MCZ 6, str. 215.

${ }_{181}$ Mirko Zjačić, Knjiga riječkog notara i kancelara Antuna de Renno de Mutina, Vjesnik historijskog arhiva u Rijeci, sv. 3, Rijeka 1957., str. 123; sv. 5, Rijeka 1959., str. 274.

182 MCZ 10, str. 133.

183 MHEZ 5, str. 135.

${ }^{184}$ MHEZ 5, str. 127-128.

185 MHEZ 6, str. 446-447.

${ }_{186}$ MCZ 6, str. 212. 
Bruno Škreblin: Uloga obiteljskih veza u formiranju gradske elite zagrebačkog Gradeca

Zb. Odsjeka povij. znan. Zavoda povij. druš. znan. Hrvat. akad. znan. umjet., 34 (2016), str. 39-87

odabrali svećenički poziv ili se na drugi način stavili u službu Kaptola nadajući se prosperitetnoj crkvenoj službi, zahvaljujući nekim svojim rodbinskim ili prijateljskim vezama s kaptolskim kanonicima i drugim službenicima zagrebačke biskupije. Andrija, sin jurata Petra Puljana, čija je kći bila udana za suca Miklina, bio je oženjen sestrom Johannesa Crispa, kalničkog arhiđakona i kanonika. ${ }^{187}$ Ivan Pavlov, osim što je bio očuh Mihaelu Sebastijanu, bio je i nećak kustosa zagrebačkog Kaptola. ${ }^{188}$ Šafari su, braneći topusku opatiju 1402. vjerojatno od četa Hrvoja Vukčića Hrvatinića (Turcos et Bosenses), bili nagrađeni sa četiri predija u Pokuplju od opata Ivana (Albena), a adoptivni sporazum Benedikta, sina Gyuana, i zagrebačkog biskupa također ukazuje da su se oni prethodno dobro poznavali.

Isto tako, pojedini građani koji su ujedno i pripadnici sitnog plemstva, mogli su se više posvetiti svojoj matičnoj zemlji koju posjeduju neovisno o svom gradskom životu. Tako većina klokočkih plemića na Gradecu i dalje posjeduje zemlju na području klokočkog distrikta, Marko od Čave ima posjede kod Bužima, Gašpar Kušević u Lominici, braća Požegaj u Egidovcu, a Ivan Šaronić, unuk Valentina Šaronića u Kosnici.

I na kraju, nevidljivost posljednje generacije neke gradske obitelji može biti i posljedica promjene dotadašnjeg uobičajenog identifikacijskog imena. Umjesto rodbinske odrednice i pozivanja na ugledne pretke, pojedini građanin može se identificirati i prema zanimanju. Tako se prisežnik Antun, sin Jurja, pojavljuje se i kao Antun nožničar. Samo zahvaljujući jednom podatku u izvorima koji na istom mjestu spominju oba identifikacijska imena, odnosno pojavljuje se Antun, sin Jurja nožničara, možemo biti sigurni da je riječ o istoj osobi. ${ }^{189}$ Ukoliko je došlo do slabljenja društvenog i ekonomskog statusa, bilo zbog mnogo nasljednika ili drugog razloga, nekadašnji sinovi uglednih sudaca prisiljeni su se baviti obrtom ili trgovinom. Barnabas, sin suca Andrije de Zwinaria, vjerojatno je identičan s Barnabasom trgovcem (institor) ${ }^{190}$ Međutim, njegovo zanimanje sada potiskuje memoriju na njegovog oca, i samo zahvaljujući istoj jezičnoj skupini u kojoj su i Andrija i Barnabas možemo s određenom sigurnošću tvrditi da se radilo o istoj obitelji, odnosno ocu i sinu.

\section{Zaključak}

Kako je još uvodno sugerirano, može se zaključiti da su na zagrebačkom Gradecu obiteljske i rodbinske veze imale znatan utjecaj na sastav magistrata. Kod sudačkih funkcija koje su u radu najviše analizirane, može se zaključiti da su afinatske veze, ne samo jednako važne kao i patrilinearne, nego se čak stječe dojam da su bile i mnogo važnije. Razlozi mogu ležati u nepostojanju primogeniture, odnosno najstariji sinovi nisu bili u prednosti pred svojom braćom ili sestrama te su svi dobili jednaki

${ }_{187}$ MCZ 1, str. 374-375.

${ }^{188}$ U popisu izopćenika 1397. među prvima je naveden bivši sudac Ivan, nećak kustosa (nepos custodis). Ivan, sin Pavla, jedini je sudac s tim imenom u to vrijeme, tako da s apsolutnom sigurnošću možemo zaključiti o kojem se građaninu radi.

189 MCZ 9, str. 151

${ }^{190}$ MCZ 6, str. 153, 271. 
Bruno Škreblin: Uloga obiteljskih veza u formiranju gradske elite zagrebačkog Gradeca Zb. Odsjeka povij. znan. Zavoda povij. druš. znan. Hrvat. akad. znan. umjet., 34 (2016), str. 39-87

dio nasljedstva. Također, znakovito je da kod patrilinearnog nasljeđivanja sudačkih funkcija, suci-očevi nisu bili živi u vrijeme kad su njihovi sinovi postali suci. Moguće da je razlog tome nesklonost gradečke elite da se među starijim sucima nađu i otac i sin, ili razlog leži u činjenici da suci u principu nisu bili u mlađim godinama pa njihovi očevi nisu doživjeli uspjeh svojih sinova. Svakako, pripadnost nekoj uglednoj obitelji davala je neophodan legitimitet za početak političke karijere, međutim visoke gradske funkcije bile su ujedno i odraz zainteresiranosti, mogućnosti i sposobnosti pojedinca.

Dugotrajne gradečke obitelji više su iznimka negoli pravilo, a razlozi su jednim dijelom biološki jer je jednostavnim obiteljima bilo teško osigurati nasljednike kroz više generacija, drugim dijelom su ekonomske prirode jer su nasljednici bili dužni ponoviti ekonomski uspjeh svojih očeva, što nije uvijek bilo moguće, osobito ako se imetak prethodno razdijelio na više nasljednika. $S$ obzirom na to da prihodi gradske elite u načelu proizlaze iz bavljenja obrtom ili trgovinom, odnosno vlastita rada, nasljednici sudaca i prisežnika morali su opet postići poslovni uspjeh da bi zadobili i onaj društveni, bez obzira na početni obiteljski "pedigre". Zbog toga je gradska elita otvorena prema novim potencijalnim članovima koji su se afirmirali svojim bogatstvom ili sposobnošću, a uz to su se ženidbeno povezali sa starijom uglednom obitelji. Tako možemo primijetiti kako se nova ugledna obitelj najčešće formira uz pomoć one starije i taj se proces kontinuirano događa tijekom gradečkog kasnosrednjovjekovlja. Možda upravo zbog svijesti postojeće elite o svojoj biološkoj slabosti s jedne, a s druge strane nedostatka vještih i bogatih ljudi u gradu, naročito od sredine 15. stoljeća, gradska je elita otvorena prema novim članovima. Ženidbenim povezivanjem sa nekom starijom obitelji novi je član elite dao jamstvo da će ostati u gradu i ponašati se u skladu s očekivanjima. Otvorenost i želja postojeće elite za novim članovima također može biti razlog prednosti afinatskih veza naspram patrilinearnih. Česti primjeri uspjeha nakon ženidbe s kćerkom nekog pripadnika gradske elite, ili udovicom, ukazuje na ulogu žena u održavanju ili stvaranju novih pripadnika gradske elite.

Također, kako se moglo vidjeti iz primjera drugih kontinentalnih gradova, Gradec se poprilično uklapa u sliku europskih kontinentalnih gradova, u kojima su također rodbinske i obiteljske veze bile od velikog značaja za društveni, odnosno politički uspjeh. Međutim, unatoč tome, kasnosrednjovjekovna gradska vijeća i upravne funkcije još uvijek su načelno otvorene za sve svoje punopravne građane i uspjeh je ipak dobrim dijelom zavisio i o interesu i sposobnosti pojedinca. Bez obzira na postojanje "vladajućih" obitelji, gradska je elita, generalno gledajući, otvorenog ili poluotvorenog tipa, jer te obitelji nisu zatvorena grupa, nego rado primaju nove članove. Takav će model ostati u srednjoeuropskim gradovima sve do kraja 16. st., nakon čega dolazi do trenda zatvaranja gradskih vijeća i stvaranja prave gradske oligarhije. 
Bruno Škreblin: Uloga obiteljskih veza u formiranju gradske elite zagrebačkog Gradeca Zb. Odsjeka povij. znan. Zavoda povij. druš. znan. Hrvat. akad. znan. umjet., 34 (2016), str. 39-87

\section{Prilog 1. Rekonstrukcija rodbinskih prethodnika u magistratu}

\begin{tabular}{|c|c|c|c|c|}
\hline iudex & prethodnik & funkcija pret. & odnos & tip \\
\hline \multicolumn{5}{|l|}{ Jacobus } \\
\hline \multicolumn{5}{|l|}{ Marcus filius Ligerii } \\
\hline \multicolumn{5}{|l|}{ Anthonius } \\
\hline Petrus Ligeri & Marcus filius Ligerri & sudac & brat? & $\mathrm{P}$ \\
\hline \multicolumn{5}{|l|}{ Mikech filius Francisci } \\
\hline \multicolumn{5}{|l|}{ Paulus } \\
\hline \multicolumn{5}{|l|}{ Johanes filius Gregori } \\
\hline \multicolumn{5}{|c|}{ Petrus iudex filius Rubini, condam } \\
\hline \multicolumn{5}{|c|}{ Nicolaus filius Benedicti } \\
\hline \multicolumn{5}{|l|}{ Mikech filius Hench } \\
\hline \multicolumn{5}{|l|}{ Marenus } \\
\hline \multicolumn{5}{|l|}{ Petrus Donatus de Medzo } \\
\hline \multicolumn{5}{|l|}{ Sebastijan } \\
\hline \multicolumn{5}{|l|}{ Johannes filius Anthoni } \\
\hline \multicolumn{5}{|l|}{ Johannes filius Laurenci } \\
\hline \multicolumn{5}{|l|}{ Stephanus frater Lourandi } \\
\hline \multicolumn{5}{|l|}{ Nicolaus Lucassi } \\
\hline \multicolumn{5}{|l|}{ Jacomellus } \\
\hline \multicolumn{5}{|l|}{ Micusius filius Ivan } \\
\hline \multicolumn{5}{|l|}{ Franciscus filius Mark } \\
\hline Johannes filius Vasas & Mikech Hench & sudac & zet & A \\
\hline \multicolumn{5}{|l|}{ Jacobus Bole } \\
\hline Luca Bonioli filius lacobi & Marco Bonioli & prisežnik & zet & A \\
\hline Myklinus filius Johannis & Andrija, sin Petra & prisežnik & zet & A \\
\hline \multicolumn{5}{|l|}{ Laurencius filius Thome } \\
\hline \multicolumn{5}{|l|}{ Nicolaus filius Odolas } \\
\hline Johannes filius Pauli & udovica Sebastijana & sudac & & A \\
\hline Johannes Bole & Jacobus Bole & sudac & $\sin$ & $\mathrm{P}$ \\
\hline \multicolumn{5}{|c|}{ Gyuan filius Benedicti de Boncarnisa } \\
\hline \multicolumn{5}{|c|}{ Petrus filius Gregori } \\
\hline \multicolumn{5}{|c|}{ Marcus filius Mykech filii Leonardi } \\
\hline \multicolumn{5}{|c|}{ Johannes filius Stephani dicti Bozo } \\
\hline Cion filius Johannis & Luca Bonioli & sudac & zet & A \\
\hline Michael filius Sebastiani & Sebastijan & sudac & $\sin$ & $\mathrm{P}$ \\
\hline Petrus filius Petri Saphar & Gyuan & sudac & $\begin{array}{l}\text { zet/ } \\
\text { veza }\end{array}$ & A \\
\hline \multicolumn{5}{|l|}{ Anthonius } \\
\hline Mychael filius Symonis & & & & \\
\hline Andreas de Zwinaria & & & & \\
\hline
\end{tabular}


Bruno Škreblin: Uloga obiteljskih veza u formiranju gradske elite zagrebačkog Gradeca Zb. Odsjeka povij. znan. Zavoda povij. druš. znan. Hrvat. akad. znan. umjet., 34 (2016), str. 39-87

\begin{tabular}{|c|c|c|c|c|}
\hline iudex & prethodnik & funkcija pret. & odnos & tip \\
\hline \multicolumn{5}{|l|}{ Johannes Prauz } \\
\hline Johannes Zigeštak & Johannes Grachyn & prisežnik & zet & A \\
\hline \multicolumn{5}{|l|}{ Johannes Pehem filius Johannis } \\
\hline Andreas Sapahr & Petrus Saphar & sudac & $\sin$ & $P$ \\
\hline \multicolumn{5}{|l|}{ Anthonius filius Appardi } \\
\hline Briccius filius Benedicti & $\begin{array}{l}\text { udovica Pere Latina iz } \\
\text { Firence }\end{array}$ & prisežnik & & A \\
\hline \multicolumn{5}{|l|}{ Georgius filius Valentini } \\
\hline \multicolumn{5}{|l|}{ Nicolaus filius Fabiani } \\
\hline \multicolumn{5}{|l|}{ Petrus filius Pauli } \\
\hline Stephanus filius Michaelis & Michael Ortoph & prisežnik & $\sin$ & $\mathrm{P}$ \\
\hline Johannes filius Pero & Pero Latin & prisežnik & $\sin$ & $\mathrm{P}$ \\
\hline Jacobus Bole & Johannes Bole & sudac & $\sin$ & $\mathrm{P}$ \\
\hline Marinus filius Clarus & Cion & sudac & veza & A \\
\hline \multicolumn{5}{|l|}{ Martinus filius Thome } \\
\hline \multicolumn{5}{|l|}{ Nicolaus filius Petri } \\
\hline \multicolumn{5}{|l|}{ Blasius filius Pauli } \\
\hline Benedictus filius Michaeli & Briccius piscator & prisežnik & zet & A \\
\hline Valentinus filius Michaeli dicti Saronych & Michael filius Symonis & sudac & $\sin$ & $\mathrm{P}$ \\
\hline Andreas filius Michaeli & $\begin{array}{l}\text { udovica Georgius de } \\
\text { Hudostech }\end{array}$ & prisežnik & & A \\
\hline \multicolumn{5}{|l|}{ Conradus Rawsar filius Wlrici } \\
\hline \multicolumn{5}{|l|}{ Johannes filius Nicolai Bolsak } \\
\hline Jacobus Eberspeck filius VIrci & $\begin{array}{l}\text { udovica Bricciusa } \\
\text { Piscatora }\end{array}$ & prisežnik & & $A$ \\
\hline Nicolaus filius Demetri & Johannes Prauz & sudac & veza & A \\
\hline Anthonius filius Thome & Vrban & prisežnik & zet & A \\
\hline Blasius filius Georgi Stojimilić & $\begin{array}{l}\text { udovica Augustina } \\
\text { Kusne }\end{array}$ & prisežnik & & A \\
\hline Thoma filius Andre & Michael Sebastijani & sudac & zet & A \\
\hline Anthonius Roth filius Johannis & $\begin{array}{l}\text { udovica Sebastijana } \\
\text { Soldinara }\end{array}$ & prisežnik & & A \\
\hline \multicolumn{5}{|l|}{ Andreas filius Symoni } \\
\hline \multicolumn{5}{|l|}{ Benedictus filius Georgi } \\
\hline \multicolumn{5}{|l|}{ Johannes filius Michaeli } \\
\hline \multicolumn{5}{|l|}{ Blasius filius Petri } \\
\hline Mathias filius Marci & Andrija, sin Šimuna & sudac & zet & A \\
\hline Johannes filius Sebastiani & Sebastijan Soldinar & prisežnik & $\sin$ & $\mathrm{P}$ \\
\hline Blasius filius Lazarin & Blaž, sin Pavla & sudac & veza & A \\
\hline Paulus filius Stephani & Michael Sebastijani & sudac & zet & A \\
\hline \multicolumn{5}{|l|}{ Laurencius institor filius Valentini } \\
\hline Dominicus filius Johannis Perowych & Johannes Perović & sudac & $\sin$ & $\mathrm{P}$ \\
\hline
\end{tabular}


Bruno Škreblin: Uloga obiteljskih veza u formiranju gradske elite zagrebačkog Gradeca Zb. Odsjeka povij. znan. Zavoda povij. druš. znan. Hrvat. akad. znan. umjet., 34 (2016), str. 39-87

\begin{tabular}{|l|l|l|l|l|}
\hline iudex & prethodnik & funkcija pret. & odnos & tip \\
\hline Georgius filius Withkonis & Blaž, sin Pavla & sudac & veza & A \\
\hline Valentinus frenipar filius Emerici Nadulen & & & & \\
\hline Emericus filius Marci & $\begin{array}{l}\text { Marko, sin Mihealea } \\
\text { Sebastijana }\end{array}$ & prisežnik & sin & P \\
\hline Jacobus filius condam Vlrici & & & & \\
\hline Gaspar Kysewych filius Pauli & & & & \\
\hline Martinus filius Vrbani & & & & A \\
\hline Fabianus filius Martini & Konrad Rawsar & sudac & veza & A \\
\hline Paulus filius Valentini & & & & \\
\hline Mathias filius Ladislaus & & & & \\
\hline Michael Oprašnić filius Anthoni & Antun Oprašnić & prisežnik & sin & P \\
\hline Emericus Mikulić filius Demetri & & & & \\
\hline Johannes filis Anthoni & & & & \\
\hline Gregorius filius Andre & & & & \\
\hline Johannes Posegaj filius Georgi & & & & \\
\hline Felix Petanyi filius Deodati & & & & \\
\hline Johannes Pastor & & & & \\
\hline Michael filius Mathei & & & \\
\hline Marcus Pozegaj filius Georgi & & & \\
\hline Stephanus filius Michaelis & & & \\
\hline
\end{tabular}

Prilog 2. Rekonstrukcija kontinuiteta sudačkih obitelji

\begin{tabular}{|l|l|l|l|}
\hline red. broj & iudex & broj mand. & sudačka obitelj \\
\hline 1. & Jacobus & 1 & \\
\hline 2. & Marcus filius Ligerii & 1 & Ligeri \\
\hline 3. & Mikech filius Francisci & 2 & \\
\hline 4. & Anthonius & 1 & \\
\hline 5. & Petrus filius Ligeri de Medio & 3 & Ligeri \\
\hline 6. & Paulus & 1 & \\
\hline 7. & Johanes filius Gregori & 1 & \\
\hline 8. & Petrus filius Rubini & 1 & \\
\hline 9. & Nicolaus filius Benedicti & 2 & Hench \\
\hline 10. & Mikech filius Hench & 1 & \\
\hline 11. & Marenus & 1 & De Medzo \\
\hline 12. & Petrus Donatus de Medzo & 1 & Sebastijan \\
\hline 13. & Sebastijan & 1 & \\
\hline 14. & Johannes filius Anthoni & 1 & \\
\hline 15. & Johannes filius Laurenci & 1 & \\
\hline
\end{tabular}


Bruno Škreblin: Uloga obiteljskih veza u formiranju gradske elite zagrebačkog Gradeca Zb. Odsjeka povij. znan. Zavoda povij. druš. znan. Hrvat. akad. znan. umjet., 34 (2016), str. 39-87

\begin{tabular}{|c|c|c|c|}
\hline red. broj & iudex & broj mand. & sudačka obitelj \\
\hline 16. & Stephanus frater Lourandi & 1 & \\
\hline 17. & Nicolaus Venis & 1 & \\
\hline 18. & Jacomellus Quirino & 1 & \\
\hline 19. & Micusius filius Ivan & 1 & \\
\hline 20. & Franciscus filius Mark & 2 & \\
\hline 21. & Johannes filius Vasas & 2 & Hench \\
\hline 22. & Jacobus Bole & 1 & Bole \\
\hline 23. & Luca Bonioli & 2 & Bonioli \\
\hline 24. & Myklinus filius Johannis & 4 & \\
\hline 25. & Laurencius filius Thome & 1 & \\
\hline 26. & Nicolaus filius Odolas & 1 & \\
\hline 27. & Johannes filius Pauli & 5 & Sebastijan \\
\hline 28. & Johannes Bole & 1 & Bole \\
\hline 29. & Gyuan filius Benedicti de Boncarnisa & 1 & Gyuan \\
\hline 30. & Petrus filius Gregori & 1 & \\
\hline 31. & Marcus filius Mykech filii Leonardi & 1 & Sebastijan \\
\hline 32. & Johannes filius Stephani dicti Bozo & 1 & \\
\hline 33. & Cion filius Johannis & 4 & Bonioli \\
\hline 34. & Michael filius Sebastiani & 3 & Sebastijan \\
\hline 35. & Petrus filius Petri Saphar & 2 & Gyuan \\
\hline 36. & Anthonius & 1 & \\
\hline 37. & Mychael filius Symonis & 2 & Šaronić \\
\hline 38. & Andreas de Zwinaria & 1 & \\
\hline 39. & Johannes Prauz & 1 & \\
\hline 40. & Johannes Zigeštak & 1 & De Medzo \\
\hline 41. & Johannes Pehem filius Johannis & 1 & Gyuan \\
\hline 42. & Andreas filius Petri Sapahr & 1 & \\
\hline 43. & Anthonius filius Appardi de Ricci & 2 & \\
\hline 44. & Briccius filius Benedicti & 1 & Briccius-Perović \\
\hline 45. & Georgius filius Valentini & 1 & \\
\hline 46. & Nicolaus filius Fabiani & 2 & \\
\hline 47. & Petrus filius Pauli & 2 & \\
\hline 48. & Stephanus filius Michaelis & 1 & De Medzo \\
\hline 49. & Johannes filius Pero & 2 & Briccius-Perović \\
\hline 50. & Jacobus Bole & 1 & Bole \\
\hline 51. & Marinus filius Clarus & 1 & Bonioli \\
\hline 52. & Martinus filius Thome & 5 & \\
\hline 53. & Nicolaus filius Petri & 3 & \\
\hline 54. & Blasius filius Pauli & 1 & Blaž štacunar \\
\hline 55. & Benedictus filius Michaeli & 1 & \\
\hline 56. & Valentinus Saronych & 5 & Šaronić \\
\hline
\end{tabular}


Bruno Škreblin: Uloga obiteljskih veza u formiranju gradske elite zagrebačkog Gradeca Zb. Odsjeka povij. znan. Zavoda povij. druš. znan. Hrvat. akad. znan. umjet., 34 (2016), str. 39-87

\begin{tabular}{|c|c|c|c|}
\hline red. broj & iudex & broj mand. & sudačka obitelj \\
\hline 57. & Andreas filius Michaeli & 1 & Briccius-Perović \\
\hline 58. & Conradus Rawsar filius Wlrici & 5 & Rawsar \\
\hline 59. & Johannes filius Nicolai Bolsak & 1 & \\
\hline 60. & Jacobus Eberspeck filius VIrci & 2 & \\
\hline 61. & Nicolaus filius Demetri & 2 & \\
\hline 62. & Anthonius filius Thome & 2 & \\
\hline 63. & Blasius filius Georgi Stojimilić & 2 & \\
\hline 64. & Thoma Croacus filius Andre & 1 & Sebastijan \\
\hline 65. & Anthonius Roth filius Johannis & 1 & Roth \\
\hline 66. & Andreas filius Symoni & 1 & Šimunić \\
\hline 67. & Benedictus filius Georgi & 2 & \\
\hline 68. & Johannes filius Michaeli & 1 & \\
\hline 69. & Blasius filius Petri & 1 & \\
\hline 70. & Mathias filius Marci & 1 & Šimunić \\
\hline 71. & Johannes filius Sebastiani & 2 & Roth \\
\hline 72. & Paulus filius Stephani & 2 & Sebastijan \\
\hline 73. & Blasius Teutonik filius Lazarin & 2 & Blaž štacunar \\
\hline 74. & Laurencius institor filius Valentini & 2 & \\
\hline 75. & Dominicus filius Johannis Perowych & 2 & Briccius-Perović \\
\hline 76. & Georgius filius Withkonis & 2 & Blaž štacunar \\
\hline 77. & Valentinus frenipar filius Nadulen & 1 & \\
\hline 78. & Emericus filius Marci & 1 & Sebastijan \\
\hline 79. & Jacobus filius condam Vlrici & 2 & \\
\hline 80. & Gaspar Kysewych filius Pauli & 1 & \\
\hline 81. & Martinus filius Vrbani & 1 & \\
\hline 82. & Fabianus filius Martini & 2 & Rawsar \\
\hline 83. & Paulus filius Valentini & 1 & \\
\hline 84. & Mathias filius Ladislaus & 2 & \\
\hline 85. & Michael Oprasnych filius Anthoni & 7 & \\
\hline 86. & Emericus Mikulić filius Demetri & 6 & \\
\hline 87. & Johannes filis Anthoni & 1 & \\
\hline 88. & Gregorius filius Andre & 1 & \\
\hline 89. & Johannes Posegaj filius Georgi & 1 & Požegaj \\
\hline 90. & Felix Petanyi filius Deodati & 1 & \\
\hline 91. & Johannes Pastor & 2 & \\
\hline 92. & Michael filius Mathei & 4 & \\
\hline 93. & Marcus Pozegaj filius Georgi & 1 & Požegaj \\
\hline 94. & Stephanus filius Michaelis & 2 & \\
\hline
\end{tabular}


Bruno Škreblin: Uloga obiteljskih veza u formiranju gradske elite zagrebačkog Gradeca Zb. Odsjeka povij. znan. Zavoda povij. druš. znan. Hrvat. akad. znan. umjet., 34 (2016), str. 39-87

Prilog 3. Rodoslovlja

\section{Obitelj Mihaela Sebastijana}

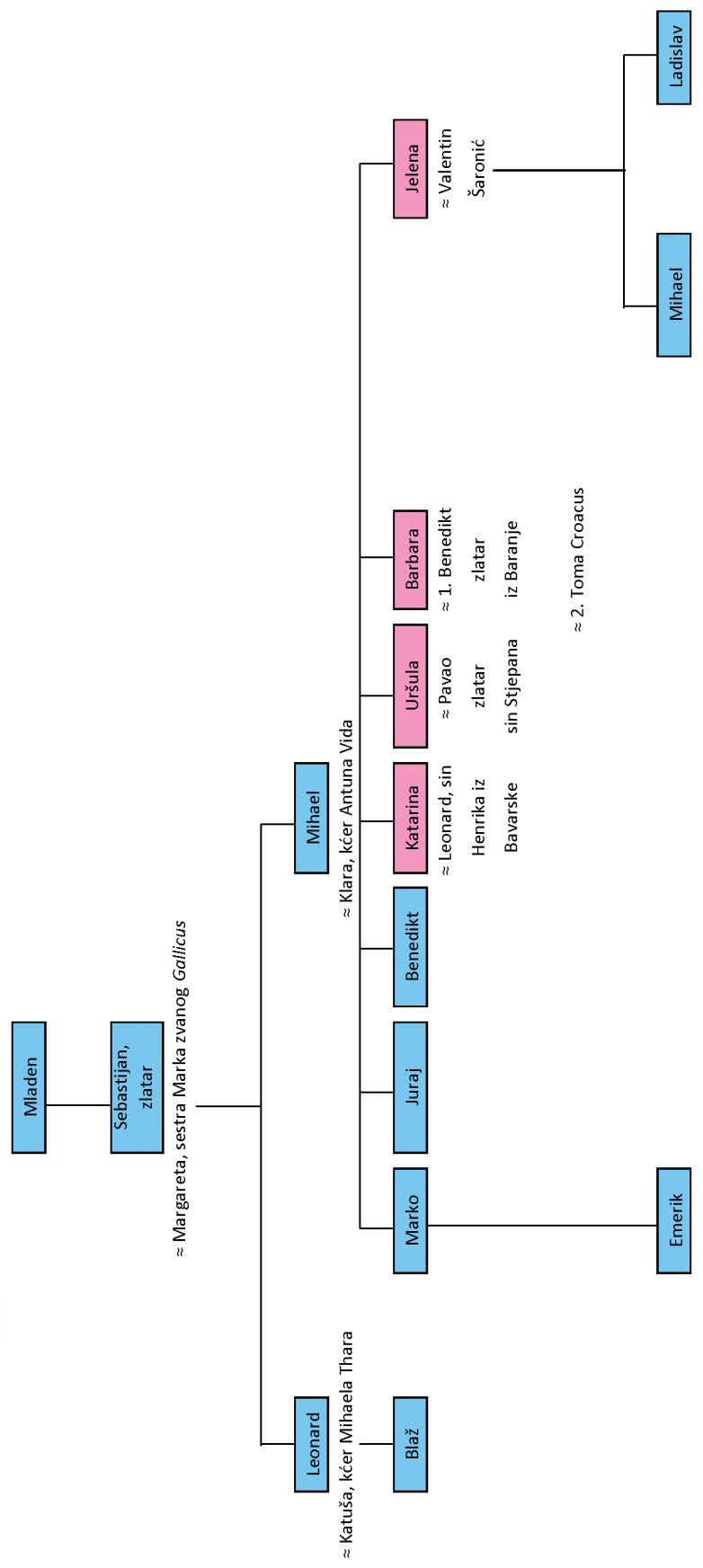


Bruno Škreblin: Uloga obiteljskih veza u formiranju gradske elite zagrebačkog Gradeca Zb. Odsjeka povij. znan. Zavoda povij. druš. znan. Hrvat. akad. znan. umjet., 34 (2016), str. 39-87

\section{Obitelj Šaronić}
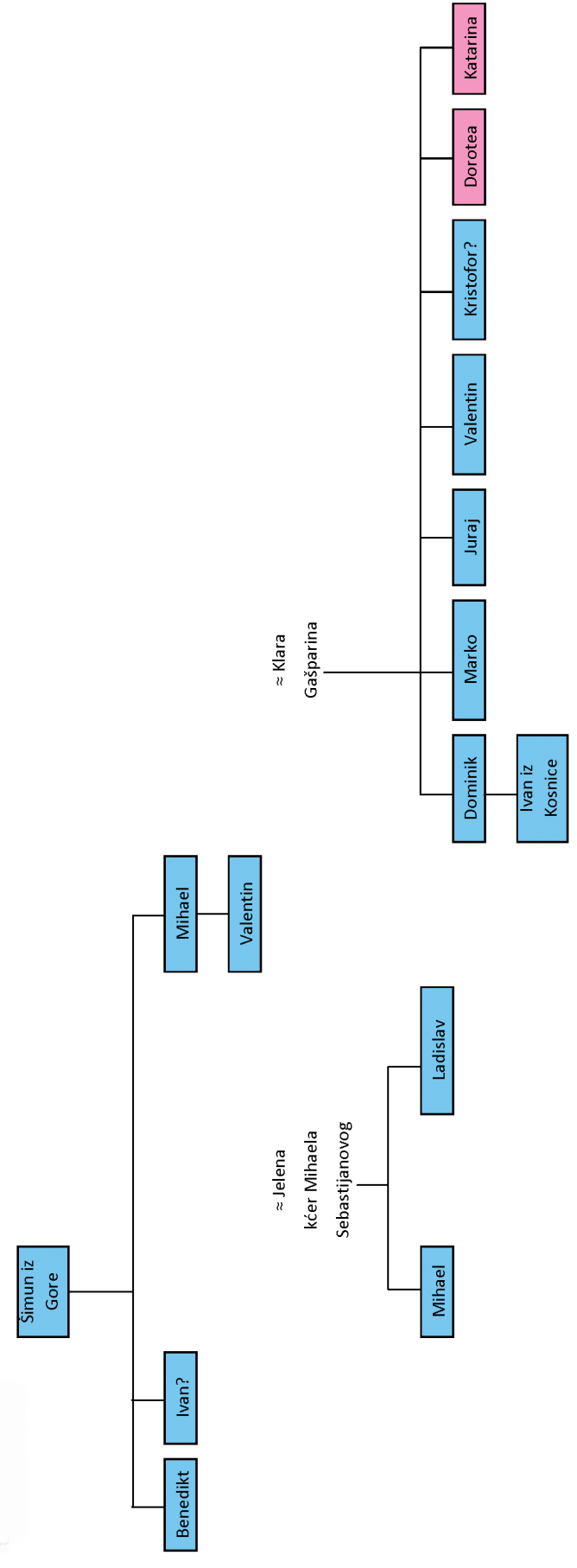
Bruno Škreblin: Uloga obiteljskih veza u formiranju gradske elite zagrebačkog Gradeca Zb. Odsjeka povij. znan. Zavoda povij. druš. znan. Hrvat. akad. znan. umjet., 34 (2016), str. 39-87

\section{Obitelj Gerinus de Spinal}

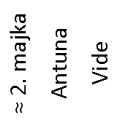

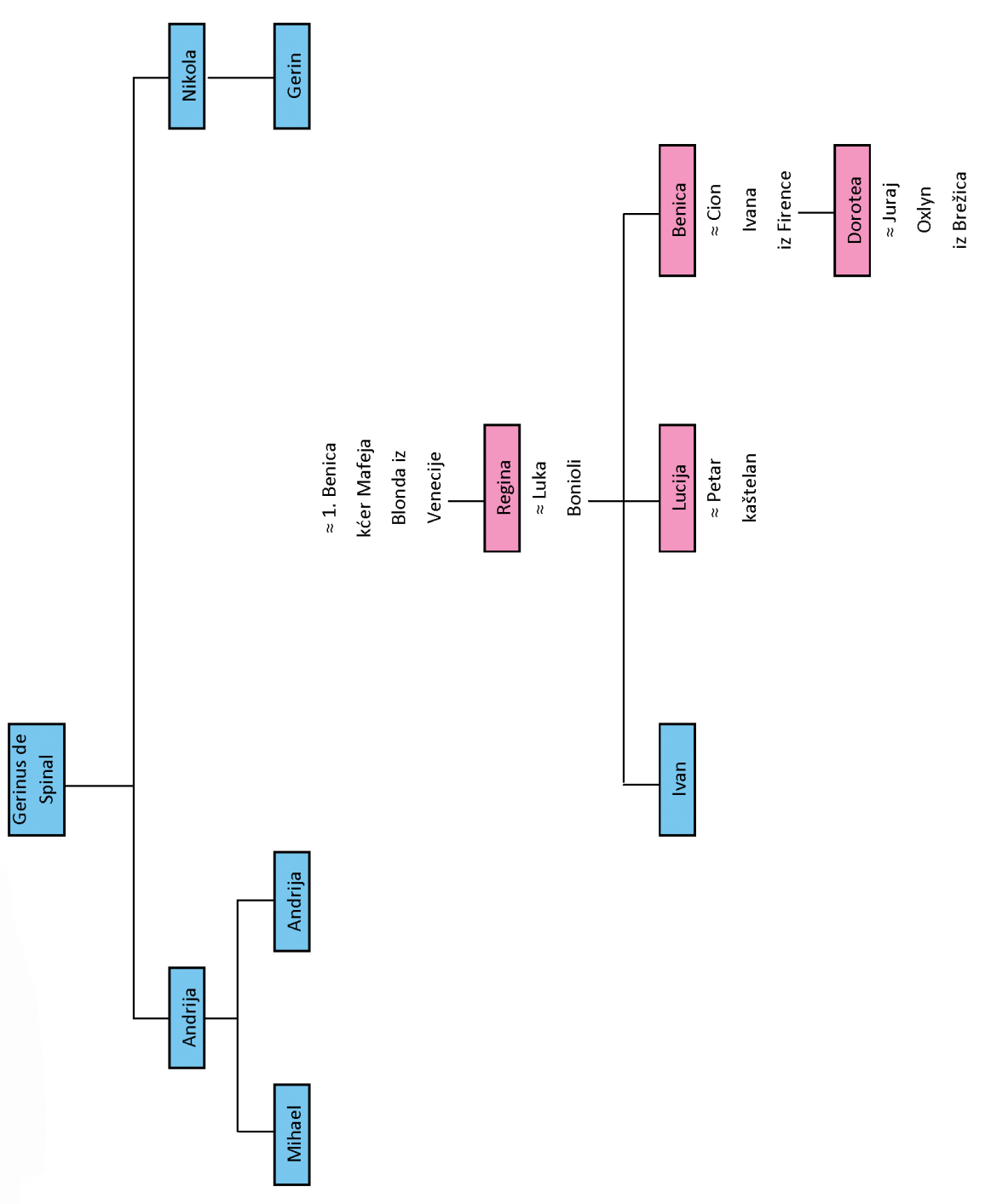


Bruno Škreblin: Uloga obiteljskih veza u formiranju gradske elite zagrebačkog Gradeca Zb. Odsjeka povij. znan. Zavoda povij. druš. znan. Hrvat. akad. znan. umjet., 34 (2016), str. 39-87

\section{Obitelj Ciona iz Firence}

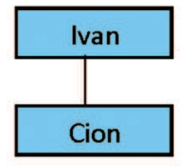

\section{$\approx 1$. Benica}

kćer Luke

Boniolija

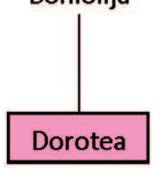

$\approx$ Juraj

Oxlyn

iz Brežica

\section{$\approx 2$. Katarina}

sestra Marina

Klarića iz

Senja

Toma

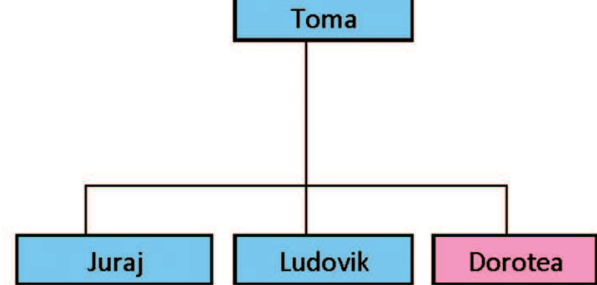


Bruno Škreblin: Uloga obiteljskih veza u formiranju gradske elite zagrebačkog Gradeca Zb. Odsjeka povij. znan. Zavoda povij. druš. znan. Hrvat. akad. znan. umjet., 34 (2016), str. 39-87

\section{Obitelj de Mezzo}
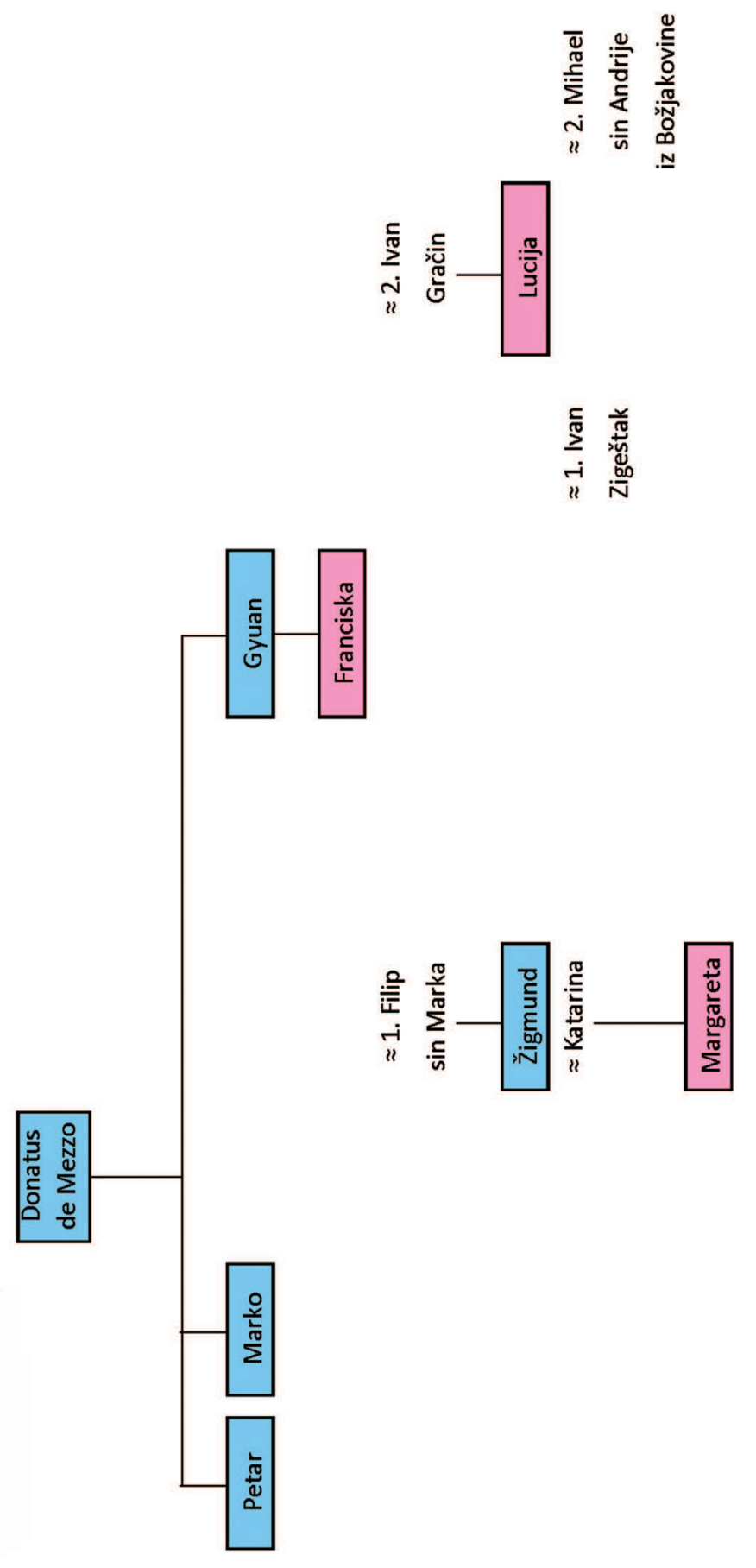
Bruno Škreblin: Uloga obiteljskih veza u formiranju gradske elite zagrebačkog Gradeca Zb. Odsjeka povij. znan. Zavoda povij. druš. znan. Hrvat. akad. znan. umjet., 34 (2016), str. 39-87

\section{Obitelj Zigeštak}

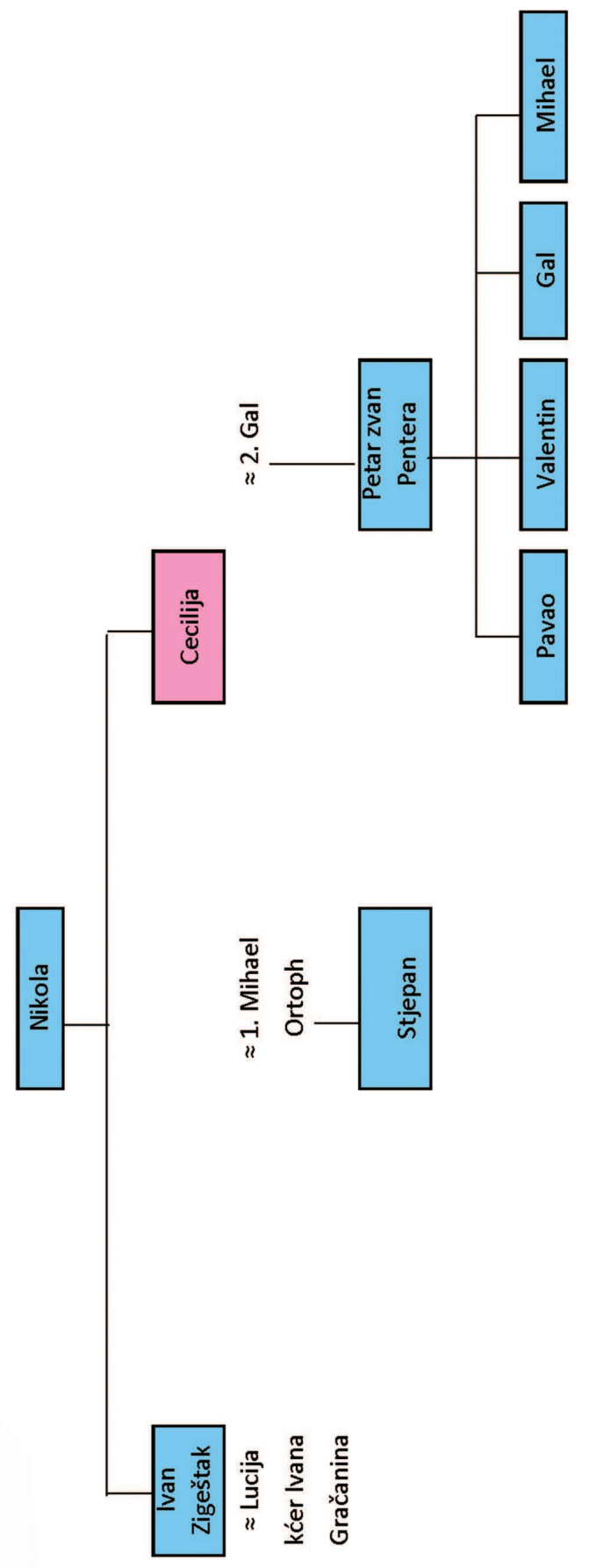


Bruno Škreblin: Uloga obiteljskih veza u formiranju gradske elite zagrebačkog Gradeca Zb. Odsjeka povij. znan. Zavoda povij. druš. znan. Hrvat. akad. znan. umjet., 34 (2016), str. 39-87

\section{Obitelj Perović}

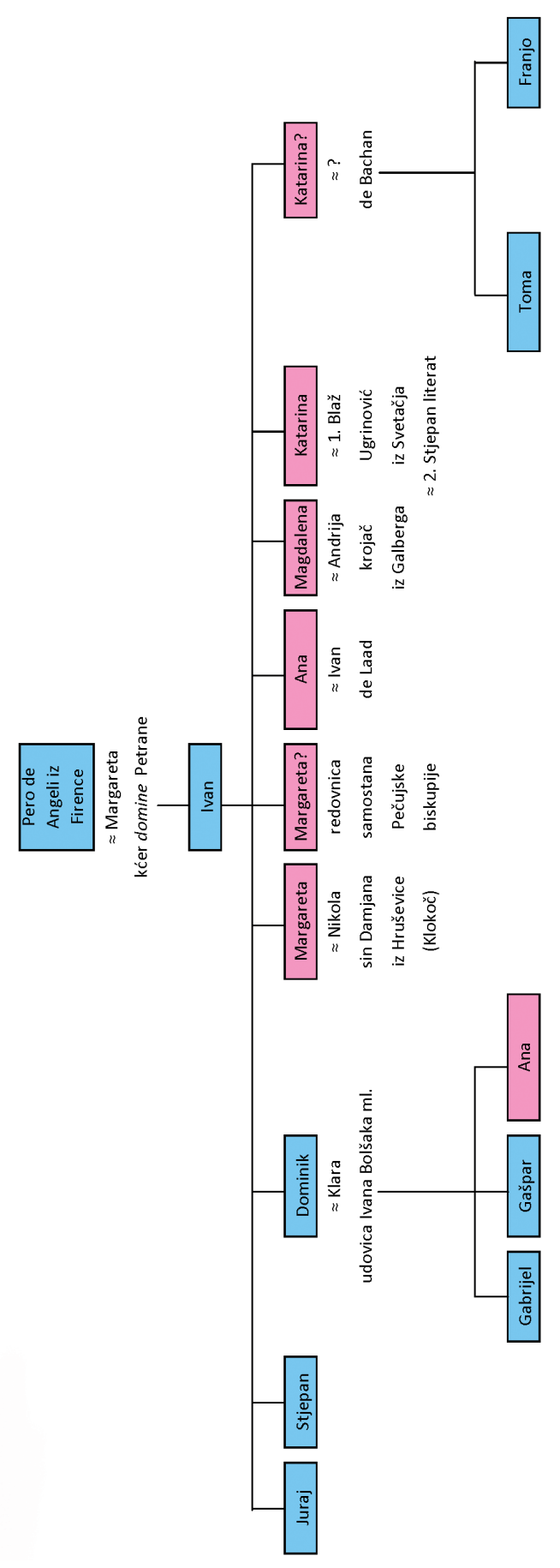


Bruno Škreblin: Uloga obiteljskih veza u formiranju gradske elite zagrebačkog Gradeca Zb. Odsjeka povij. znan. Zavoda povij. druš. znan. Hrvat. akad. znan. umjet., 34 (2016), str. 39-87

\section{Obitelj Gyuan - Šafar}

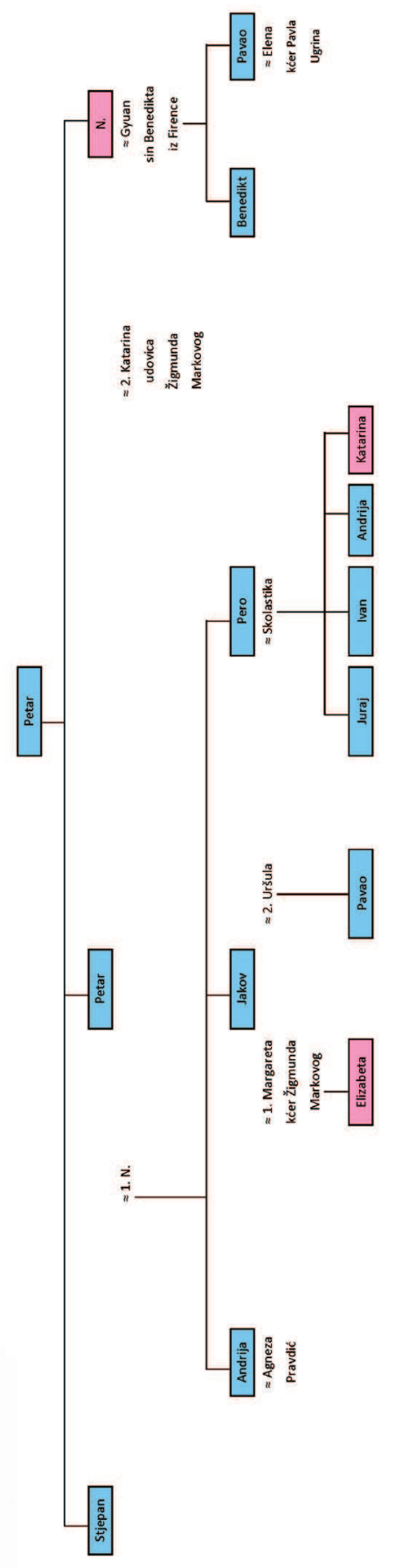


Bruno Škreblin: Uloga obiteljskih veza u formiranju gradske elite zagrebačkog Gradeca Zb. Odsjeka povij. znan. Zavoda povij. druš. znan. Hrvat. akad. znan. umjet., 34 (2016), str. 39-87

\section{Obitelj Blaža, sina Pavla}

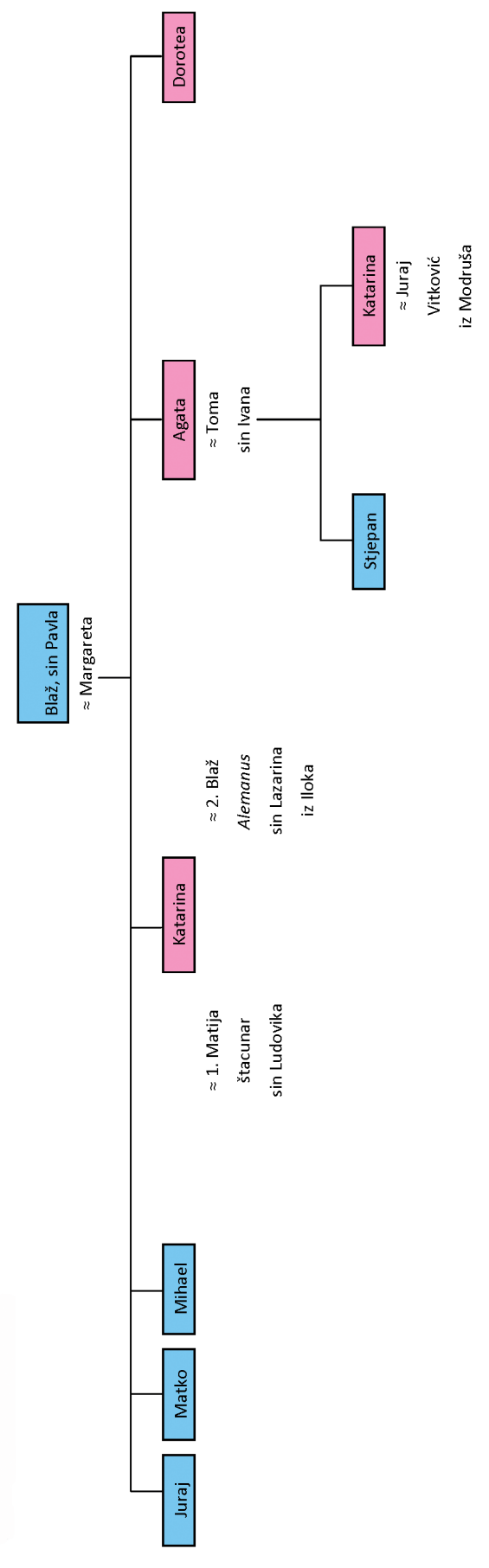


Bruno Škreblin: Uloga obiteljskih veza u formiranju gradske elite zagrebačkog Gradeca Zb. Odsjeka povij. znan. Zavoda povij. druš. znan. Hrvat. akad. znan. umjet., 34 (2016), str. 39-87

\section{Obitelj Bole}

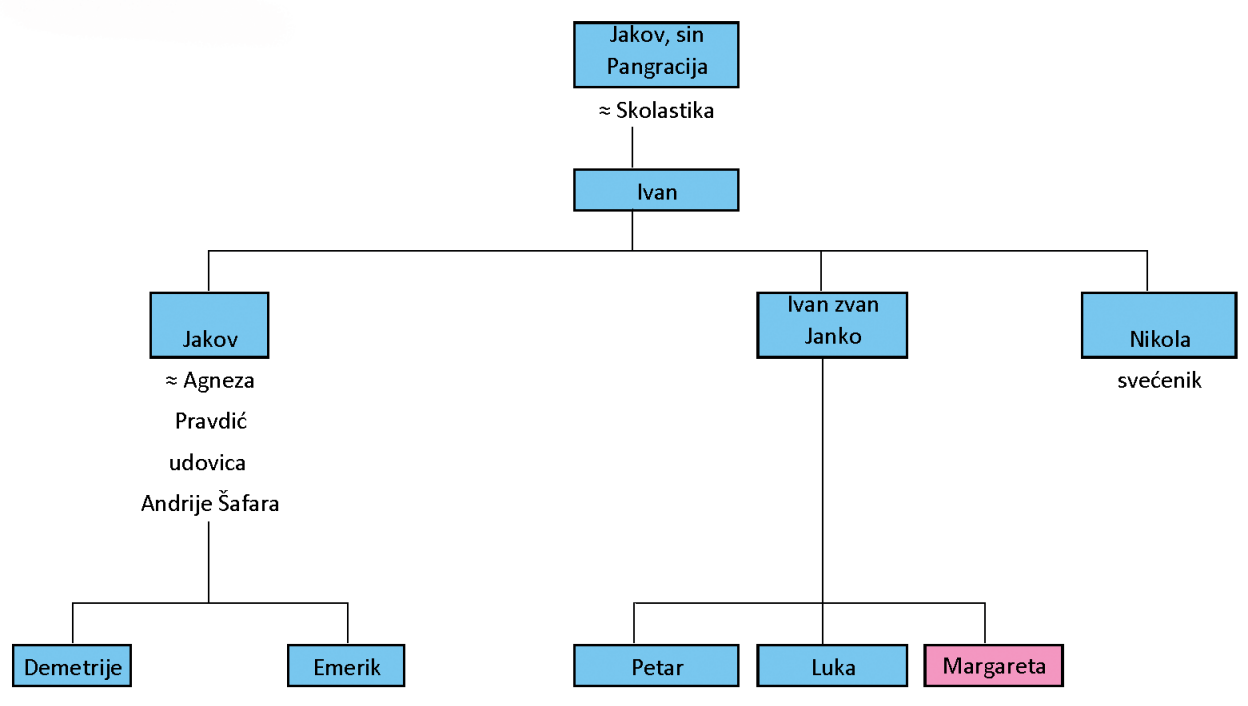


Bruno Škreblin: Uloga obiteljskih veza u formiranju gradske elite zagrebačkog Gradeca Zb. Odsjeka povij. znan. Zavoda povij. druš. znan. Hrvat. akad. znan. umjet., 34 (2016), str. 39-87

Bruno Škreblin

\title{
The Role of Family Ties in the Formation of the Urban Elite of the Gradec of Zagreb
}

\begin{abstract}
Summary
Kinship and family ties exercised a great influence on the composition of the city magistracy, especially on the highest function within the magistracy, that of city judge and jurors. Belonging to an important family secured social reputation and status, and it was frequently the case that members of the same families held different positions within the same magistracy. It is particularly evident that city judges very frequently had some family member or kinsman who had served in previous years in the magistracy. Out of a total of 94 citizens who held the position of the city judge in the period considered here, from 1350 to 1525, family and kinship connections with some previous jurors and judges are established for 33 of them. Most frequently, the type of connection was affinal: that is to say, judges were most frequently sons-in-law or husbands of widows of former judges or jurors. There were fewer recorded patrilinear connections, and it is important to stress the rarity of cases of inheriting the function of judge on the basis of the patrilinear principle: it is established in only five cases that father and son held the position of city judge. Sons of judges more frequently remained only jurors or councillors. The importance of belonging to some distinguished family may be seen also in the fact that in Gradec at least fourteen different families could be identified whose closer or more distant members held the positions of judges for a shorter or longer period. However, the urban elite was not closed: many members of these families were in fact newcomers in the city, who obtained additional repute by marrying a daughter or a widow of some respectable citizen. Almost a third of the city judges in the period under research were newcomers, and for many of them it is established that they were connected by marriage to some older respectable family. In that fact, there may be observed the role of women in creating, integrating and consolidating urban elites. If only the biological aspect is considered, then we may say that long-lasting families in Gradec were the exception rather than the rule, because for only two families may it be established that they lasted in local politics for four generations, and very few lasted through three generations. The reasons for the disappearance of particular families were partly of a biological nature, caused by the high rate of mortality in medieval cities, and partly of an economic nature. The latter is frequently connected to inheritance-related matters, because sons and daughters of respected citizens had a right to equal shares of property, and thus, if a respected citizen had more children, an equal part of the inheritance belonged to each of them. Because of that, only rarely might sons live off their fathers' inheritance, and they had to maintain their fathers' success in business to retain their social standing.
\end{abstract}

Key words: Gradec of Zagreb, urban elite, family history, the Middle Ages, social history 